\title{
New species and nomenclatural changes in Angraecum (Orchidaceae) from Madagascar
}

\author{
Johan Hermans $^{1,2}$ (D), Simon Verlynde ${ }^{3,4}$, Landy Rajaovelona ${ }^{5}$, Phillip J. Cribb ${ }^{1}$ \& Jean-Michel Hervouet ${ }^{6}$
}

Summary. Three new species: Angraecum archangelicum, A. polyphemus and A. rotundifolium are described for the first time. Pectinariella is evaluated; a case is made to keep it at subgeneric level and the necessary two new combinations are made. Angraecum dasycarpum is neotypified. Finally A. ochraceum and A. setipes are compared with the latter being reduced to a synonym of the former.

Key Words. IUCN Red List assessments, new species descriptions, Pectinariella, taxonomy, Vandeae.

\section{Introduction}

Angraecum Bory (1804: t. 19) comprises around 225 species, occurring mainly in Africa, Madagascar and adjacent islands of the Indian Ocean. Madagascar has the greatest number of species, around 150, most of which are endemic (Hermans et al. 2007; Govaerts et al. 2018). Following the major work on the Madagascan angraecoid orchids by Schlechter (1918b, 1924) and Perrier de la Bâthie (henceforth Perrier) (1938, 1941), Garay (1973) produced a taxonomic revision of the genus at sectional level. Several investigations of the phylogeny and biogeography of the genus have recently been made (Michenau et al. 2008; Szlachetko et al. 2013; Andriananjamanantsoa et al. 2016; Simo-Droissart et al. 2018a). In addition Senghas (1964, 1997), Bosser (1970, 1988, 1989a \& b, 2007), Hermans \& Cribb (1997, 2005), Hermans \& la Croix (2001), Hermans et al. (2002), Cribb et al. (2012), Verlynde et al. (2016) and Hermans (2017) have all recently described novelties in the genus from the island.

Recent studies on the genus at Kew, the Missouri Botanical Garden, the University of Vienna, and PBZT Antananarivo have resulted in the recognition of a number of new species and a better understanding of their nomenclature. Three new species are described and several nomenclatural changes are outlined here.
Because of the limitations of herbarium material available for completing some of the drawings, it was not always possible to represent all the detail of the gynostemium; more detailed notes from field observations were added to the text.

\section{IUCN Red List assessments}

The conservation status of the new species given in this paper are summaries of the full IUCN Red List assessments which will be completed and submitted for review and publication by IUCN once the species names are validly published and therefore available for assessment. All the assessments have been compiled based on current knowledge of these taxa, using the IUCN Red List Categories and Criteria $(2012,2017)$.

\section{New Species}

Angraecum archangelicum Hermans $\mathcal{E}$ Sieder sp. nov. Type: Madagascar, Fianarantsoa prov., Antoetra, 1727 m, on granite inselberg, 15 Feb. 2015, Sieder, Pertl $\mathcal{E}$ Andriantiana, 6871 (WU342015) (holotype WU!).

http://www.ipni.org/urn:lsid:ipni.org:names:77211711-1

Pendent to semi-erect epiphytic or lithophytic herb up to $11 \mathrm{~cm}$ long. Roots, branched, silvery, glabrous,

\footnotetext{
Accepted for publication 21 November 2019. Published online 9 December 2020

1 Herbarium, Royal Botanic Gardens, Kew, Richmond, Surrey, TW9 3AE, UK. e-mail: j.hermans@kew.org

2 Core Facility, Botanical Garden, University of Vienna, Rennweg 14, 1030, Vienna, Austria.

${ }^{3}$ Cullman Program for Molecular Systematics, New York Botanical Garden, 2900 Southern Blvd, The Bronx, NY, 10458, USA.

4 Program in Biology, Graduate Center, City University of New York, 365 5th Ave, New York, NY, 10016, USA.

5 Kew Madagascar Conservation Centre, Lot II J 131 Ambodivoanjo, Ivandry, Madagascar.

${ }^{6} 61$ rue du Lieutenant Ricard, Chatou, France.
} 
somewhat flattened, $4-6 \mathrm{~mm}$ in diam. Stem woody, covered with scarious bracts, c. $3-5 \mathrm{~cm}$ long, c. $1 \mathrm{~cm}$ in diam. with $3-4$ leaves, the base covered with the old corrugate, brown leaf sheaths. Leaves glaucous, distichous, narrowly ligulate-lanceolate, somewhat falcate at the apex, $6-16 \mathrm{~cm}$ long, $0.7-1.5 \mathrm{~cm}$ wide, the base narrowing and laterally compressed into a sheath c. $2 \mathrm{~cm}$ long. Inflorescences lateral, emerging from the base of the stem, pendent to divergent at c. $45^{\circ}$ to the stem, $5-7 \mathrm{~cm}$ long, with $1-2$ flowers and an embryonic bud at the base, the occasional second flower on a short branch of the inflorescence. Peduncle thin, rigid, $6-8 \times 2-4 \mathrm{~mm}$, green, with $1-3$ brownish green sterile bracts, the old ones persistent. Floral bracts thin-textured, enclosing the base of the pedicellate ovary, $1.6-2.4 \times 1.2-1.8 \mathrm{~mm}$, brownish green. Flowers non-resupinate with the lip uppermost, spreading, up to $20 \times 12 \mathrm{~mm}$, pale yellowish green, shiny, the lip and column a little paler, apex of the spur green, column white. Pedicel and ovary terete then twisted and more grooved towards the base, $7.9-9.2 \times$ $0.8-1.2 \mathrm{~mm}$, green. Dorsal sepal pendent, broadly lanceolate, attenuate, $9.8-11.5 \times 4.5-5.5 \mathrm{~mm}$, the margins recurved. Lateral sepals erectly spreading, broadly lanceolate, attenuate, $6.9-7.2 \times 2.7-3 \mathrm{~mm}$. Petals erect, broadly falcate, attenuate, $7.9-9.2 \times 2.8-$ $3.2 \mathrm{~mm}$, recurved in the apical third. Lip cucullate, ovate-lanceolate, $6.7-7.5 \times 3.8-4.1 \mathrm{~mm}$, acuminate, with a broadly thickened longitudinal callus, the apical margins strongly incurved and partly fused at the apex; spur somewhat recurved, clavate, $9.8-10.6 \times 1.2$ $-2.6 \mathrm{~mm}$. Column ovoid to globose, c. $1.5 \times 2 \mathrm{~mm}$, lateral lobes of the rostellum attenuate at the front, c. $1 \mathrm{~mm}$ long, stigma ovoid, c. $0.5 \mathrm{~mm}$ in diam.; anther cap elliptic, with a small lobule at the front, with two distinct chambers, c. $1 \times 1.2 \mathrm{~mm}$; pollinia ovoid c. $0.5 \times$ $0.6 \mathrm{~mm}$, two lorate stipes with an small triangular viscidium. Figs 1, 2.

RECOGNITION. With its sub-acaulous habit and relatively small flowers on an elongate peduncle the new species belongs in section Boryangraecum Schltr. (Schlechter 1925: 308). Within the section it is distinguished by the combination of its relatively large habit with long narrow leaves and its pendent, long, rigid peduncle. It can also be recognised by its non-resupinate flowers, relatively large erect petals, the broad central vein within the lip and its clavate spur. It is closest to Angraecum aviceps Schltr. (Schlechter 1925: 335) known from Bemarivo in the NE of Madagascar. Schlechter's description is short and the type specimen has been missing from P for many years. From the description it is clear that its leaves are shorter, the inflorescence has more flowers $(3-5$ vs $1-2)$ and is produced earlier in the year, and the flowers are a little smaller, with smaller petals and a subfiliform spur (vs clavate). It is also similar to A. calceolus Thouars
(1822: t. 78) but the habit and inflorescence of that species are very different, the spur is generally longer (much longer than the ovary vs about the same length), the dorsal sepal shorter $(6-8 \mathrm{~mm}$ vs over $10 \mathrm{~mm}$ ), the petals not erect and the lip of a different shape. It also shows some similarities in habit and inflorescence to A. ochraceum (Ridl.) Schltr. (Schlechter 1915: 436) but that species has much smaller flowers of a different shape and a spur at least 3 times longer than the ovary.

DISTRIBUTION. The new species is endemic to central Madagascar; it is known from the type specimen but also from photographs taken by Jean-Michel Hervouet and Gilles Grunenwald in Ambondrombe and Ankaratra respectively.

SPECIMEN EXAMINED. MADAGASCAR. Fianarantsoa prov., Antoetra, Feb. 2015, 1727 m, Sieder, Pertl E Andriantiana 6871 (WU342015) (equivalent number Hermans 8091) (holotype WU!).

HABITAT. Lithophyte on granite inselberg, epiphyte on 'tapia' (Uapaca bojeri Baill.) dominant forest. Altitude $1600-1700 \mathrm{~m}$.

CONSERVATION STATUS. Angraecum archangelicum is endemic to Madagascar, distributed in the Central Highland in Amoron'I Mania, Haute-Matsiatra and Vakinankaratra regions, Antananarivo and Fianarantsoa provinces. It occurs in three defined threat locations and is not recorded from any Protected Areas. The extent of occurrence EOO, the area of occupancy AOO and the habitat quality are currently not known but are very likely in continuing decline due to major threats such as frequent fires. Therefore, it is assessed as Endangered (EN) under criterion $\mathrm{B} 1 \mathrm{ab}(\mathrm{i}, \mathrm{ii}, \mathrm{iii})+2 \mathrm{ab}(\mathrm{i}, \mathrm{ii}, \mathrm{iii})$ according to the IUCN Red List Categories and Criteria.

FLOWERING TIME. February - April.

ETYMOLOGY. Referring to the resemblance of the flowers to a group of descending archangels.

NOTES. The species was briefly described and illustrated by Guérin \& Hervouet (2011: 97) and Hervouet (2018: 153) as an unidentified species (Angraecum sp. 2).

Angraecum polyphemus Hermans $\mathcal{E}$ Verlynde sp. nov. Type: Madagascar, Antsiranana prov., near Joffreville, Fontenay, c. 900 m, Jan. 1993, Hermans 8127 (holotype $\mathrm{K} !)$.

http:/ /www.ipni.org/urn:lsid:ipni.org:names:77211712-1

Semi-erect or pendent flabellate epiphytic herb up to $5 \mathrm{~cm}$ long, on a very short stem; roots wiry, cylindrical, glabrous, c. $1 \mathrm{~mm}$ in diam. Stem $3-8 \times 2-4 \mathrm{~mm}$, flattened, the base covered with dried leaf and peduncle sheaths. Leaves up to 9, distichous, twisted at the base so as to lie in a single plane containing the stem axis, conduplicate at base at the transition to the 


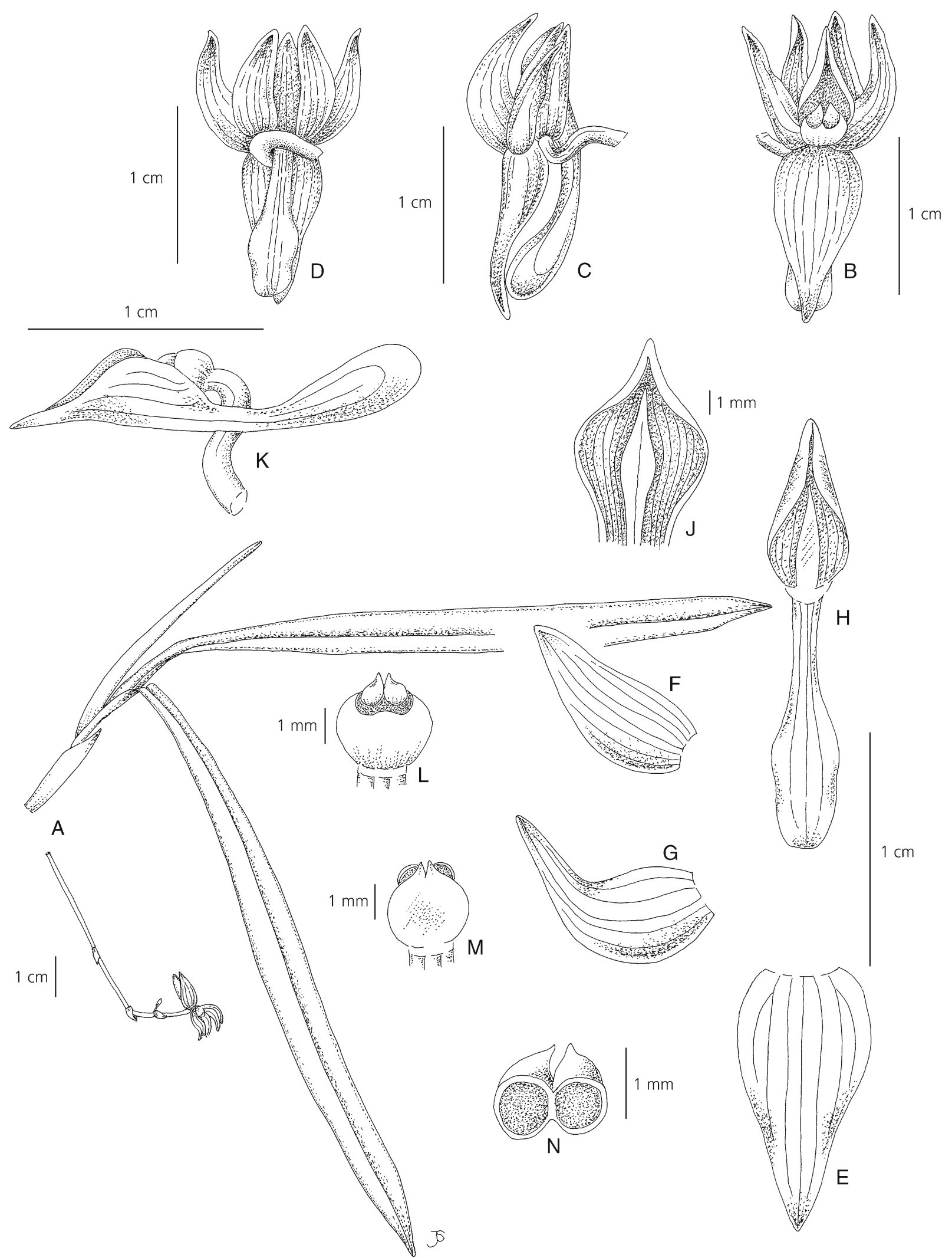

Fig. 1. Angraecum archangelicum. A part of habit from photographs; B flower, dorsal view; C flower, side view; D flower ventral view; E dorsal sepal; F lateral sepal; G petal; $\mathrm{H}$ lip; J lip lamina opened out; K lip, column, ovary and pedicel, side view; L column, dorsal view; M column, ventral view; $\mathbf{N}$ anther cap. Based on Hermans 8091. DRAWN BY JUDI STONE. 

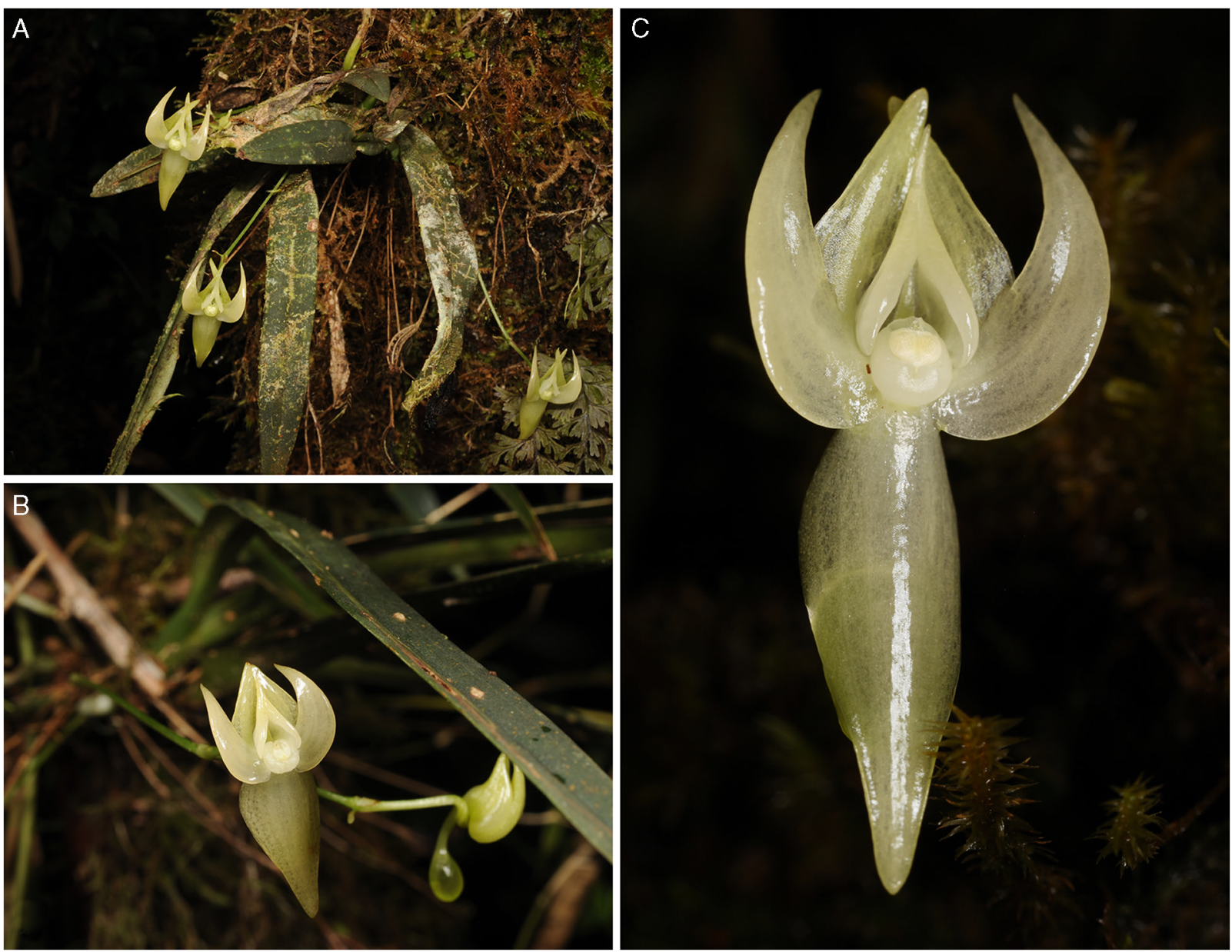

Fig. 2. Angraecum archangelicum. A habit in habitat; B inflorescence; C flower, face view. PHOTOS: JEAN-MICHEL HERVOUET.

leaf sheaths, ligulate to lanceolate, $10-29 \times 2.5-6$ $\mathrm{mm}$, the margins a little thinner, flat canaliculate on top, roundly keeled below with the mid-vein ending in an apicule before the attenuate unequally bilobed leaf tip, on a short $2-4 \times 1-1.2 \mathrm{~mm}$ petiole. Inflorescence axillary, short, diverging, $10-15 \mathrm{~mm}$ long, single or rarely 2-flowered with an embryonic bud at the apex. Peduncle slender, $6-9 \mathrm{~mm}$, flattened, capitate at the tip, persistent, peduncle sheath attenuate, $2.5-3.9 \times 1$ - $1.5 \mathrm{~mm}$. Floral bracts lanceolate, 2.5 - $4 \times 1.1-1.8$ $\mathrm{mm}$, attenuate. Flowers non-resupinate with the lip uppermost, $8-11 \times 6-8 \mathrm{~mm}$, white except for the apex of the spur, which is green and, the anther which has yellowish green cross-shaped bands in the middle. Pedicel and ovary obconical, incurved, glabrous, 6.5 $8.3 \times 1-1.3 \mathrm{~mm}$. Dorsal sepal convex, obovate to elliptic-obovate, $4.8-5.1 \times 1.9-2.2 \mathrm{~mm}$, apiculate at the apex. Lateral sepals convex, obovate to ellipticobovate, $4.6-4.9 \times 2.2-2.4 \mathrm{~mm}$, apiculate at the apex. Petals oblong-obovate, $4.5-5 \times 1.6-1.8 \mathrm{~mm}$, subapiculate at the apex. Lip 3-lobed with the lateral lobes erect and parallel to the column and the midlobe upturned, $4.9-5.4 \times 5.2-5.6 \mathrm{~mm}$, the lateral lobes sinuate at the anterior margin, the mid-lobe sinuate to undulate at the margin, emarginate to acute at the apex, the base with a few scattered thin hairs; spur almost parallel to the ovary, clavate, rounded at the apex, slightly arcuate, $4.3-4.7 \times 1.2-1.9 \mathrm{~mm}$. Column ovoid, $2-2.2 \times 1.7-1.8 \mathrm{~mm}$, lateral lobes of the rostellum roundly lobed, c. $1.5 \mathrm{~mm}$ long, midlobe lobular, stigma ovoid, c. $0.8 \mathrm{~mm}$ in diam.; anther cap elliptic, produced with a long bilobed part at the front, with two distinct chambers, $1.7-1.9 \times 1.2-1.4 \mathrm{~mm}$; pollinia 2 , ovoid, c. $1 \times 0.7 \mathrm{~mm}$, with two lorate stipes and a small angular viscidium. Figs 3, 4.

RECOGNITION. Angraecum polyphemus belongs in section Pectinaria (Benth.) Schltr. (Schlechter 1918b: 157) for its habit and usually single-flowered on a short peduncle. It is distinct by its flabellate habit on a very short stem with relatively wide ligulate to lanceolate flat leaves lacking a dorsal wing, and its comparatively large flower(s) with the lip uppermost, with broad rounded side lobes, a sinuate anterior margin with a few hairs at the base and a relatively long clavate spur and an anther with a large lobe at the front. It is 


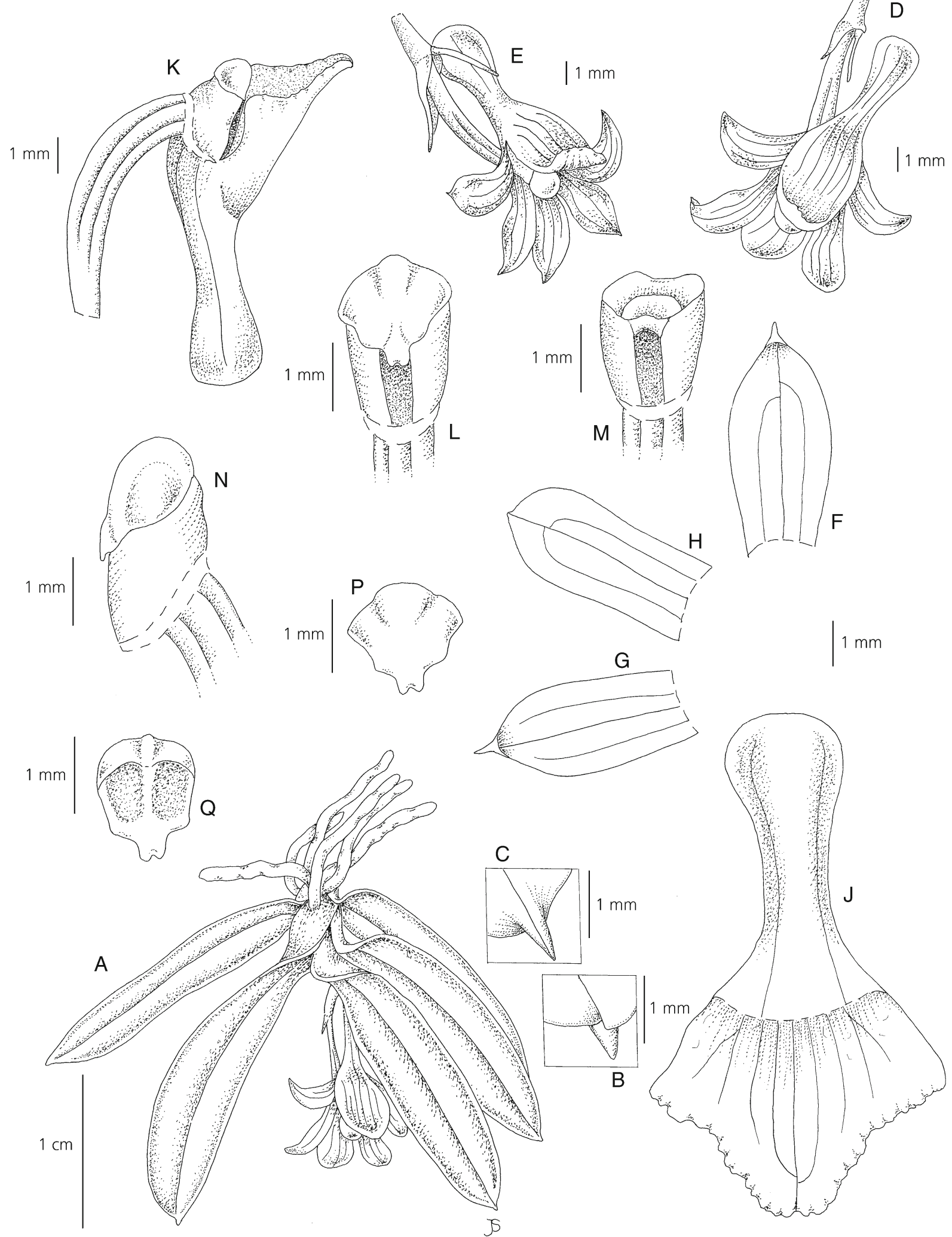

Fig. 3. Angraecum polyphemus. A habit; B leaf apex, dorsal view; C leaf apex, ventral view; D flower, front view; E flower, ventral view; F dorsal sepal; G lateral sepal; $\mathrm{H}$ petal; J lip; K lip, column, ovary and pedicel, side view; L column, front view, with anther cap in place; $\mathbf{M}$ column, front view, anther cap removed; $\mathbf{N}$ column, with anther cap, side view; P anther cap, dorsal view, Q anther cap, ventral view. Based on Hermans 8127. DRAWN BY JUDI STONE. 

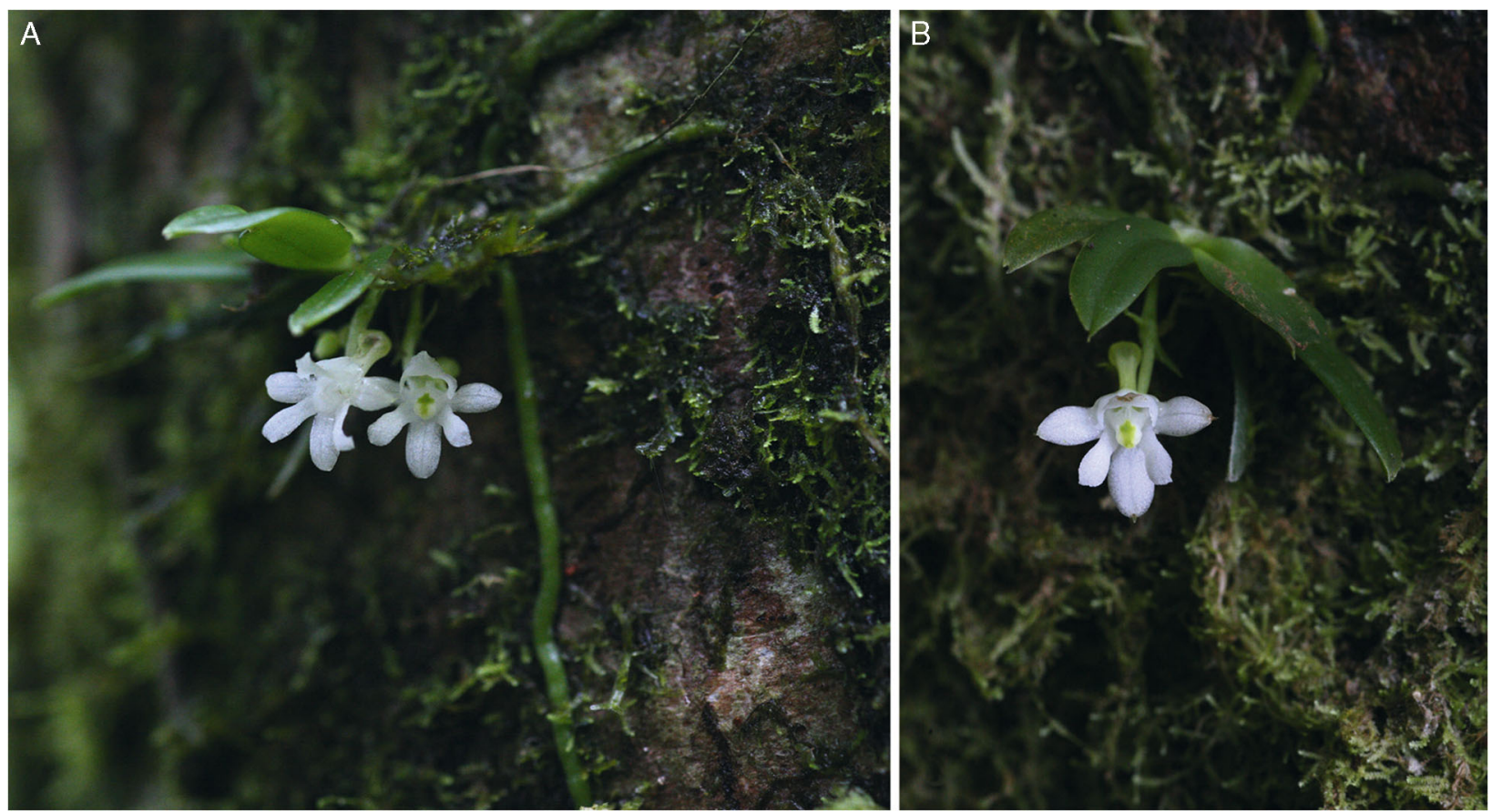

Fig. 4. Angraecum polyphemus. A plant in habitat; B flower, face view. PHOTOS: JOHAN HeRmans.

different in habit and flower from most of the other species in section Pectinaria (but there are a number of similarities with $A$. edmundi (Verlynde \& Ramand.) Hermans \& Verlynde, A. pterophyllum H.Perrier (1938: 106) and A. scroticalcar (Verlynde \& Ramand.) Hermans \& Verlynde, including the short peduncle, 1 to rarely 2 flowers, thickened apicule at the apex of petals and sepals, 3-lobed lip with hairs at the base and relatively short thickened spur. It differs from all three by its very short stem, flat ligulate-lanceolate leaves that are roundly keeled (vs thin-flattened below), the different arrangements of the leaves which are generally fewer in number, twisted at the base and arranged in one plane containing the stem axis (vs not twisted at the base and arranged in more than one plane perpendicular to the stem axis), the larger flowers (twice the size of $A$. edmundi and A. scroticalcar, and about a quarter larger than A. pterophyllum), the lateral lobes of the lip less distinct with sinuate anterior margins (vs entire (except in A. edmundi)), fewer hairs at the base of the lip. The spur is similar but is more elongate than the other species (almost twice the length) and more arching. Table 1.

DISTRIBUTION. Angraecum polyphemus is endemic to Madagascar and found in the provinces of Antananarivo, Antsiranana and Toamasina.

SPECIMENS EXAMINED. MADAGASCAR. Antsiranana prov., Diana region, near Joffreville, Fontenay, c. 900 m, Jan. 1993, Hermans 8127 (holotype K!); Antananarivo prov., Analamanga region, Andramasina distr., commune de Takafara, Kelilalina, Ambohimanga, 1625 m, May 2015, fl., Antananarivo Spirit Collection
90T6 (TAN!); same locality, Feb. 2017, fl., Antananarivo Spirit Collection 322T75bis (TAN!); Toamasina prov., Alaotra-Mangoro region, Moramanga distr., Ampitambe fokontany, commune rurale d'Ambohobary, between Tapimbato and Berano, $1206 \mathrm{~m}, \mathrm{Jan} .2005$, fl., Razanatsoa 102 (MO, P!, TAN!); Ambatovy forest, 1134 - $1151 \mathrm{~m}$, April 2012, fl., Ambatovy Spirit Collection 358A950 (TAN!); same locality, Feb. 2014, fl., Ambatowy Spirit Collection 1419VB818 (TAN!); same locality, March 2014, fl., Ambatovy Spirit Collection 1561VB1744 (TAN); same locality, March 2014, fl., Ambatovy Spirit Collection 1562VB1745 (TAN); same locality, March 2014, fl., Ambatovy Spirit Collection 1563VB1746 (TAN); Antsinanana region, Vatomandry distr., commune d'Ambalabe, 770 - 780 m, April 2016, fl., Ambalabe Spirit Collection 59L561 (TAN).

HABITAT. Epiphyte in humid evergreen forest, on tree trunks, $0.5-1 \mathrm{~m}$ from the ground. Altitude 770 - $1631 \mathrm{~m}$.

CONSERVATION STATUS. Angraecum polyphemus is endemic to Madagascar, distributed in Analamanga, Antsiranana (Joffreville), Diana and Alaotra-Mangoro regions, Antananarivo (Ambohimanga), Antsiranana and Toamasina (Moramanga) provinces. The extent of occurrence (EOO) of A. polyphemus is estimated to be over 24,749 $\mathrm{km}^{2}$ (which exceeds the limits for Vulnerable status under criterion B1) whereas its minimal area of occupancy (AOO) is estimated to be $24 \mathrm{~km}^{2}$ (which falls within the limits for Endangered status under the criterion B2). This species is known from two specimens collected in distinct protected 
Table 1. Comparison of the main characteristics of Angraecum scroticalcar, A. pterophyllum, A. edmundi and A. polyphemus, the first three based on Verlynde et al. (2016: 228).

\begin{tabular}{|c|c|c|c|c|}
\hline & Angraecum scroticalcar & Angraecum pterophyllum & Angraecum edmundi & Angraecum polyphemus \\
\hline Plant & $\begin{array}{l}1.4-4 \mathrm{~cm}, \text { erect with } \\
\text { distinct stem }\end{array}$ & $\begin{array}{l}1.4-6.7 \mathrm{~cm} \text {, pendent with } \\
\text { distinct stem }\end{array}$ & $\begin{array}{l}2-4 \mathrm{~cm} \text {, erect with distinct } \\
\text { stem }\end{array}$ & $\begin{array}{l}\text { up to } 5 \mathrm{~cm} \text {, suberect and } \\
\text { subacaulous }\end{array}$ \\
\hline Leaves & $\begin{array}{l}4-12,6-18 \times 1-2 \mathrm{~mm} \text {, } \\
\text { conduplicate, elliptic, } \\
\text { fleshy, margins recurved, } \\
\text { not twisted at the base } \\
\text { arranged in more than } \\
\text { one plane perpendicular } \\
\text { to stem axis }\end{array}$ & $\begin{array}{l}4-21,8-37 \times 2-3.5 \mathrm{~mm}, \\
\text { conduplicate, linear, } \\
\text { fleshy, margins recurved, } \\
\text { not twisted at the base } \\
\text { arranged in more than } \\
\text { one plane perpendicular } \\
\text { to stem axis }\end{array}$ & $\begin{array}{l}4-15,8-19 \times 1.5-3 \mathrm{~mm}, \\
\text { linear, fleshy canaliculate, } \\
\text { margins recurved, not } \\
\text { twisted at the base } \\
\text { arranged in more than } \\
\text { one plane perpendicular } \\
\text { to stem axis }\end{array}$ & $\begin{array}{l}4-9,10-20 \times 2.5-6 \\
\text { mm, flat, lanceolate to } \\
\text { ligulate, twisted at the } \\
\text { base so as to lie in one } \\
\text { plane containing the } \\
\text { stem axis }\end{array}$ \\
\hline Flowers & $\begin{array}{l}1 \text { - 2, } 4 \mathrm{~mm} \text { long, segments } \\
\text { 3-veined }\end{array}$ & $\begin{array}{l}\text { Single, } 5.5-7 \mathrm{~mm} \text { long, } \\
\text { segments 3-veined }\end{array}$ & $\begin{array}{l}1 \text { - 2, 3.5 mm long, } \\
\text { segments 3-veined }\end{array}$ & $\begin{array}{l}1-2,8-10 \mathrm{~mm} \text { long, } \\
\text { segments 3-veined }\end{array}$ \\
\hline $\begin{array}{l}\text { Dorsal } \\
\text { sepal }\end{array}$ & ovate, $2 \times 0.8 \mathrm{~mm}$ & ovate, $3-5 \times 2-2.5 \mathrm{~mm}$ & ovate, $2 \times 1-1.5 \mathrm{~mm}$ & $\begin{array}{l}\text { ovate, } 4.8-5.1 \times 1.9-2.2 \\
\mathrm{~mm}\end{array}$ \\
\hline $\begin{array}{l}\text { Lateral } \\
\text { sepals }\end{array}$ & $\begin{array}{l}\text { obovate, keeled, acuminate, } \\
\quad 2 \times 1 \mathrm{~mm}\end{array}$ & $\begin{array}{l}\text { obliquely ovate, somewhat } \\
\text { keeled, acuminate, } \\
4 \times 3 \mathrm{~mm}\end{array}$ & $\begin{array}{l}\text { obliquely ovate, somewhat } \\
\text { keeled, acuminate, } \\
2.5-3 \times 1.5 \mathrm{~mm}\end{array}$ & $\begin{array}{l}\text { ovate, } 4.6-4.9 \times 2.2 \times 2.4 \\
\text { mm }\end{array}$ \\
\hline Petals & $\begin{array}{l}\text { ovate, subapiculate, } \\
2 \times 1 \mathrm{~mm} \text {, not keeled }\end{array}$ & $\begin{array}{l}\text { obovate, subapiculate, } 2.5- \\
4 \times 1.8-2.3 \mathrm{~mm} \text {, fleshy, } \\
\text { not keeled }\end{array}$ & $\begin{array}{l}\text { obovate, rounded or } \\
\text { subacute at the tip, } 1 / 5- \\
2 \times 1.2 \mathrm{~mm} \text {, not keeled }\end{array}$ & $\begin{array}{l}\text { obovate-spatulate, } 4.5-5 \\
\quad \times 1.6-1.8 \mathrm{~mm} \text {, } \\
\text { subacute, somewhat } \\
\text { keeled }\end{array}$ \\
\hline Lip & $\begin{array}{l}\text { 3-lobed, lateral lobes short } \\
0.8 \mathrm{~mm} \text { long and acute, } \\
\text { mid-lobe subapiculate at } \\
\text { the apex } 1.2 \times 1.5 \mathrm{~mm} \text {, } \\
\text { base with hyaline hairs, } \\
1.8 \mathrm{~mm} \text { long }\end{array}$ & $\begin{array}{l}\text { 3-lobed, lateral lobes oval } \\
\text { rounded at the apex, c. } \\
1.5 \mathrm{~mm} \text { long not acute } \& \\
\text { erect folded against the } \\
\text { colum } \mathrm{n}, \mathrm{mid}-1 \text { o b e } \\
\text { broadly subangular, } \\
\text { rounded and apiculate } \\
\text { at the tip } 2 \times 2.2 \mathrm{~mm} \text {, } \\
\text { base with short hyaline } \\
\text { hairs, } 3.5-4.5 \mathrm{~mm} \text { long }\end{array}$ & $\begin{array}{l}\text { 3-lobed, lateral lobes short } \\
\text { erect, rounded, 0.8 mm } \\
\text { long, mid-lobe bigger, } \\
\text { subrectangular } 1.5 \times 1.5 \\
\text { mm, truncate and } \\
\text { subapiculate at the tip, } \\
\text { base with thinning } \\
\text { hyaline hairs, } 2.5-3 \mathrm{~mm} \\
\text { long }\end{array}$ & $\begin{array}{l}\text { 3-lobed subequal, lateral } \\
\text { lobes rounded, mid- } \\
\text { lobe emarginate, a few } \\
\text { hairs at the base, not } \\
\text { apiculate, } 4.9-5.4 \times 5.2 \\
-5.6 \mathrm{~mm}\end{array}$ \\
\hline Spur & $\begin{array}{l}\text { cylindrical, apex scrotiform, } \\
2.2 \times 0.7 \mathrm{~mm}\end{array}$ & $\begin{array}{l}\text { clavate, } 2-2.5 \mathrm{~mm} \text { long, } \\
\text { rounded at the apex }\end{array}$ & $\begin{array}{l}\text { ampulliform, } 1.5-2 \mathrm{~mm} \\
\quad \text { long }\end{array}$ & clavate, $4.3-4.7 \mathrm{~mm}$ long \\
\hline Column & $\begin{array}{l}\text { rostellum bilobed, } \\
\text { lobes acute, } 3 \mathrm{~mm} \text { long }\end{array}$ & $\begin{array}{l}\text { rostellum bilobed, lobes } \\
\text { acute or truncate, } \\
0.8-2 \mathrm{~mm} \text { long }\end{array}$ & $\begin{array}{l}\text { rostellum bilobed, } \\
\quad \text { lobes truncate, } 1 \mathrm{~mm} \text { long }\end{array}$ & $\begin{array}{l}\text { rostellum roundly } \\
\text { bilobed, c. } 2 \mathrm{~mm} \text { long }\end{array}$ \\
\hline Anther cap & hemispheric, $0.6-0.8 \mathrm{~mm}$ & $\begin{array}{l}\text { hemispheric, } 1-1.3 \mathrm{~mm} \text {, } \\
\text { with a narrow } 0.5-1 \mathrm{~mm} \\
\text { lobe at the front }\end{array}$ & $\begin{array}{l}\text { hemispheric, } 0.5-0.6 \mathrm{~mm} \text {, } \\
\text { with a narrow c. } 0.3 \mathrm{~mm} \\
\text { lobe at the front }\end{array}$ & $\begin{array}{l}\text { ellipsoid, } 1.7-1.9 \times 1.2- \\
1.4 \mathrm{~mm} \text { with a long } \\
\text { bilobed lobule at the } \\
\text { front }\end{array}$ \\
\hline Distribution & $\begin{array}{l}\text { Toamasina prov., } \\
\text { Eastern forest }\end{array}$ & $\begin{array}{l}\text { Antananarivo, } \\
\text { Fianarantsoa, Toamasina } \\
\text { prov., widespread }\end{array}$ & $\begin{array}{l}\text { Antananarivo prov., } \\
\text { central }\end{array}$ & $\begin{array}{l}\text { Antananarivo, } \\
\text { Antsiranana \& } \\
\text { Toamasina prov. }\end{array}$ \\
\hline $\begin{array}{l}\text { Altitude } \\
\qquad(\mathbf{m})\end{array}$ & $0-1500$ & $1000-1700$ & $700-1700$ & $700-1600$ \\
\hline $\begin{array}{l}\text { Flowering } \\
\text { time }\end{array}$ & August & August to April & February to August & January to May \\
\hline
\end{tabular}

areas, one from the Parc National de la Montagne d'Ambre, and one from the Corridor Ankeniheny Zahamena. In addition to these officially protected sites, eight specimens of this species have also been collected in unprotected forests subjected to forest clearing, selective logging, timber harvesting for small-scale subsistence and tavy (slash-and-burn farming). This species is thus known from ten specimens representing three existing and one partially extirpated subpopulation. These four subpopulations represent a total of four "locations" (sensu IUCN 2012) with respect to the main threat of habitat destruction, falling within the limit for Endangered status. We estimate that the past loss of its habitat, which will continue, has and will induce a strong continuous decline in habitat quality, number of subpopulations and mature individuals in the next ten years as well as a decline of its AOO. Angraecum polyphemus is therefore assigned a status of EN B2ab(i,ii,iii,iv,v).

FLOWERING TIME. January to May.

ETYMOLOGY. Referring to Polyphemus from Greek mythology, with the central column and anther cap resembling the eye of the monster and the clubshaped spur the weapon often carried by the same mythical creature.

NOTES. Flowering plants of this species have recently (Jan. 2017) been observed in the Montagne d'Ambre 
National Park by several of the authors.

Angraecum rotundifolium Hermans sp. nov. Type: Madagascar, Toamasina prov., Andasibe, edge of Mantadia forest near Vakôna lodge, $1060 \mathrm{~m}$, May 2001, Hermans 5573 (holotype K!).

http:/ /www.ipni.org/urn:lsid:ipni.org:names:77211713-1

Small scrambling epiphytic herb up to $15 \mathrm{~cm}$ long, appressed to the substrate; with a few branched roots along the stem, wiry, a little verrucose, c. $1 \mathrm{~mm}$ in diam. Stem branching and sub-branching, up to $13 \mathrm{~cm}$ long, a little flattened, the base covered by old corrugate leaf sheaths. Leaves coriaceous, alternatedistichous along the stem, the mature ones appressed against the substrate, elliptic to oblong, $6-6.5 \times 3.5-3.8 \mathrm{~mm}$, flat with a rounded mid-vein underneath, obtuse to rounded at the base, unequally bilobed at the apex, pale to dark green, the surface foveolate. Inflorescence divaricate, very short, singleflowered, leaf-opposed, with an embryonic flower bud at the base. Peduncle short, angular in crosssection, c. $4-5 \times 1 \mathrm{~mm}$, covered by $2-3$ thin sterile bracts. Floral bracts ovate, conduplicate, dorsally ridged, $1.8-2.2 \times 1-1.3 \mathrm{~mm}$, creamy-white. Flowers passively resupinate, overall $6-7 \times 5-7 \mathrm{~mm}$, crystalline white, the anther and pollen yellowish. Pedicel and ovary fusiform, $3-5 \times 0.9-2 \mathrm{~mm}$, echinate to shortly hirsute, pale ochre with the thorny hairs brown especially along the longitudinal furrows. Dorsal sepal broadly lanceolate, $4-5.1 \times 1.8-2 \mathrm{~mm}$, obtuse, a little recurved at the apex. Lateral sepals lanceolate acute, $4.2-6 \times 1.8-2.1 \mathrm{~mm}$, spreading, recurved. Petals broadly lanceolate, $3.3-4.2 \times 0.8-1.2 \mathrm{~mm}$, acute, spreading, recurved. Lip ovate when flattened, $4-5 \times$ $2.5-3.8 \mathrm{~mm}$, obtuse to acute, with rounded lobes in the basal third, anterior margin often involute, spur opening narrow, cylindrical towards the base then scrotiform and flattened, $2.2-4 \times 1-2.1 \mathrm{~mm}$. Column very short, rounded, with distinct falciform lateral rostellum lobes folded in front, apex of rostellum deeply emarginate with a small subulate central lobe, 1 - $1.2 \times 1-1.2 \mathrm{~mm}$, stigma oval, c. $1 \mathrm{~mm}$ in diam. Anther cap semi-globose with a raised rounded lobe, 0.9 - $1.2 \times 0.8-1 \mathrm{~mm}$; pollinia 2 , obovoid, c. $0.2 \times 0.4 \mathrm{~mm}$, with strap-like stipes and a small viscidium c. $0.3 \mathrm{~mm}$ long. Figs 5, 6.

RECOGNITION. A small branching plant, lying flat on the substrate, and with small elliptic to oblong leathery leaves, a short single-flowered inflorescence, and small flowers with an echinate to shortly hirsute ovary, an ovate lip roundly lobed at the base, a spur that is cylindrical towards the base, then scrotiform and flattened, and a column with falciform rostellum lobes folded at the apex. With its habit and solitary small flower on a short peduncle Angraecum rotundifolium is placed in section Pectinaria of the genus. Its flowers are somewhat similar to those of A. pectinatum Thouars (1822: t. 51) and A. humblotianum (Finet) Schltr. (Schlechter 1915: 434) but its habit is very different with broad, rounded leaves (vs elongate-linear or almost terete) and flowers with a spur that is also a little shorter and scrotiform (vs cylindrical). With its branching leafy stem and small flower it has frequently been confused with the superficially similar A. dasycarpum Schltr. (Schlechter 1918a: 337) circumscribed below, but it is different in several characteristics which are not always obvious in herbarium materials: the plant grows flat against the substrate (vs the somewhat erect growth of A. dasycarpum), and has flat, elliptic to oblong leaves (vs ovate-lanceolate slightly divergent to the stem), tepals that are consistently around half the size, a scrotiform spur (vs cylindrical narrowing towards the tip), an echinate to shortly hirsute ovary (vs longly hirsute) and a column with prominent angular ribs (vs rounded). Its distribution is also different, with A. rotundifolium recorded only from the eastern forest near Andasibe in Toamasina province at c. 600 - 1000 $\mathrm{m}$ where it flowers from February to May, whereas A. dasycarpum is found in north-eastern Madagascar in lower elevation forest where it flowers from August to November. Table 2.

DISTRIBUTION. Endemic to Toamasina province in eastern Madagascar.

SPECIMENS EXAMINED. MADAGASCAR. Toamasina prov., Andasibe, edge of Mantadia near Vakôna, May 2001, 1060 m, Hermans 5573 (holotype K!); Toamasina Alaotra-Mangoro, c. $22 \mathrm{~km} \mathrm{NE}$ of Moramanga, Ambohibary, 1006 m, March 2005, Rakotovao 1635 (TAN!); Toamasina, Antsinanana, Andrangato R., 638 m, March 2011, Antilahimena 7583 (MO, TAN!); Toamasina, Atsinanana, Andrangato R., 1582 m, March 2011, Antilahimena E Randrimitantsoa 7591 (TAN!); Toamasina, Ambatovy, 2013, 995 - 1005 m, Ambatovy Shade House 2293 (BRLU, K!, MO, P!, TAN!); Toamasina, Ambatovy, Feb. 2013, 995 - 1005 m, Ambatovy Spirit Collection 1485A2293/2 \& Collection 3106A2335/1 (MO, TAN!); Hort. Malala Orchidées, ex Hill, 2015, Hermans 7037 (K!); Ambavaniasy, 907 m, Feb. 2015, 2016, A. E C. Sieder, Pertl. E Andriantiana SKA 6756 (= Hermans 8079) (K!, WU!); Toamasina, Ambatovy: Région Alaotra Mangoro, 995 m, Feb. 2016, Ambatovy Spirit Collection 2853A2293/6 (TAN).

HABITAT. Humid evergreen forest, in dense Pandanus forest and on Uapaca. Altitude 600-1000 m.

CONSERVATION STATUS. Angraecum rotundifolium is endemic to Madagascar, distributed in Alaotra-Mangoro and Atsinana regions, Toamasina province. It occurs in the Andasibe-Mantadia and Ambatovy Protected Areas. The area of occupancy AOO is estimated to be 


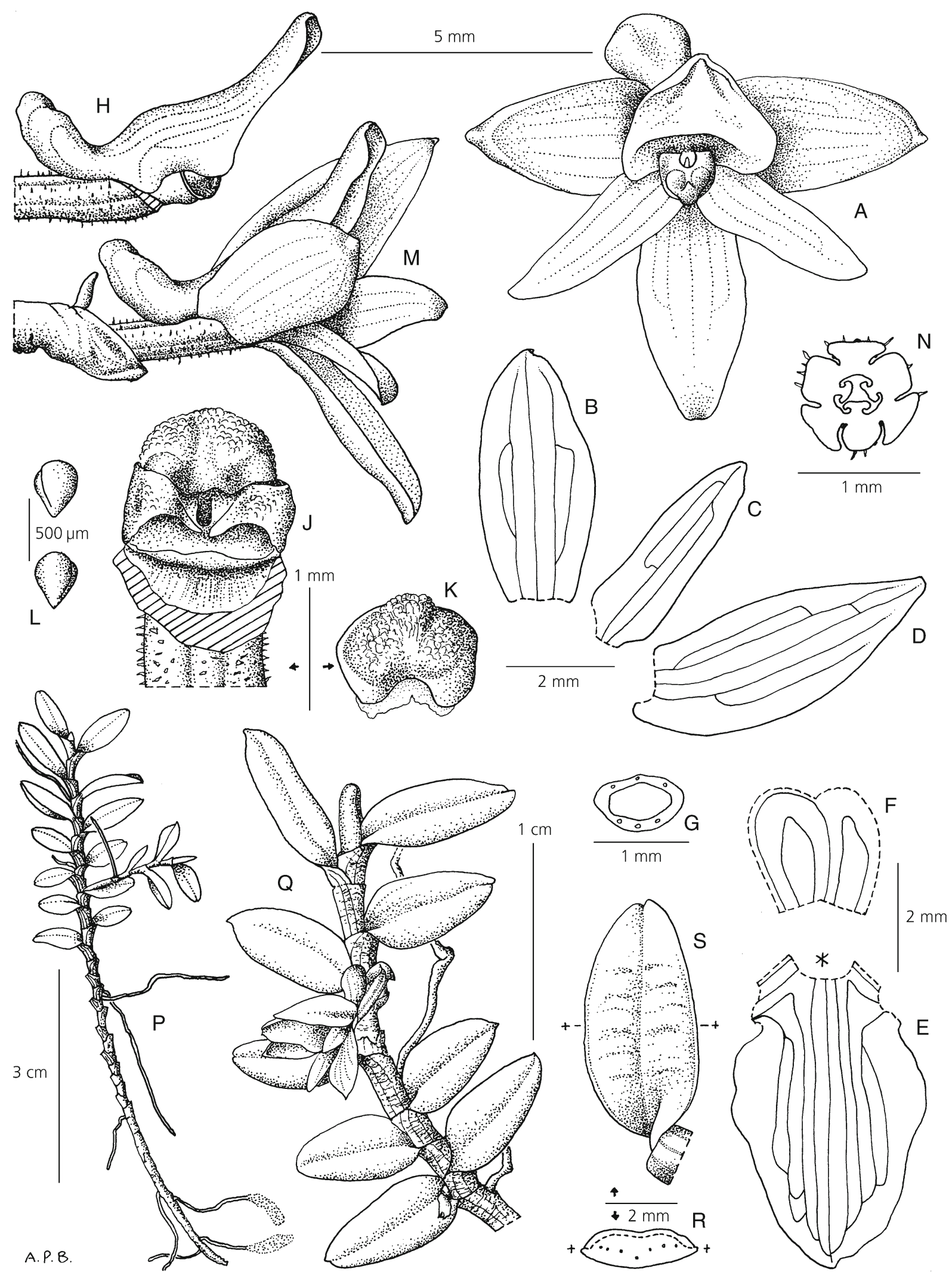

Fig. 5. Angraecum rotundifolium. A flower, face view; B dorsal sepal; C petal; D lateral sepal; E lip \& proximal region of spur, flattened spur cut along dorsal mid-line; F distal portion of spur, flattened, spur cut along dorsal mid-line; G T.S. spur at *; H column and lip, lateral view; J column, ventral view; K anther cap, dorsal view; L pollinia; M flower, lateral view; N T.S. ovary; P habit, whole plant; Q habit, portion of flowering plant; R leaf, T.S.; S adaxial surface of leaf. From Hermans 5573, spirit material. DRAWN BY ANDREW BROWN. 

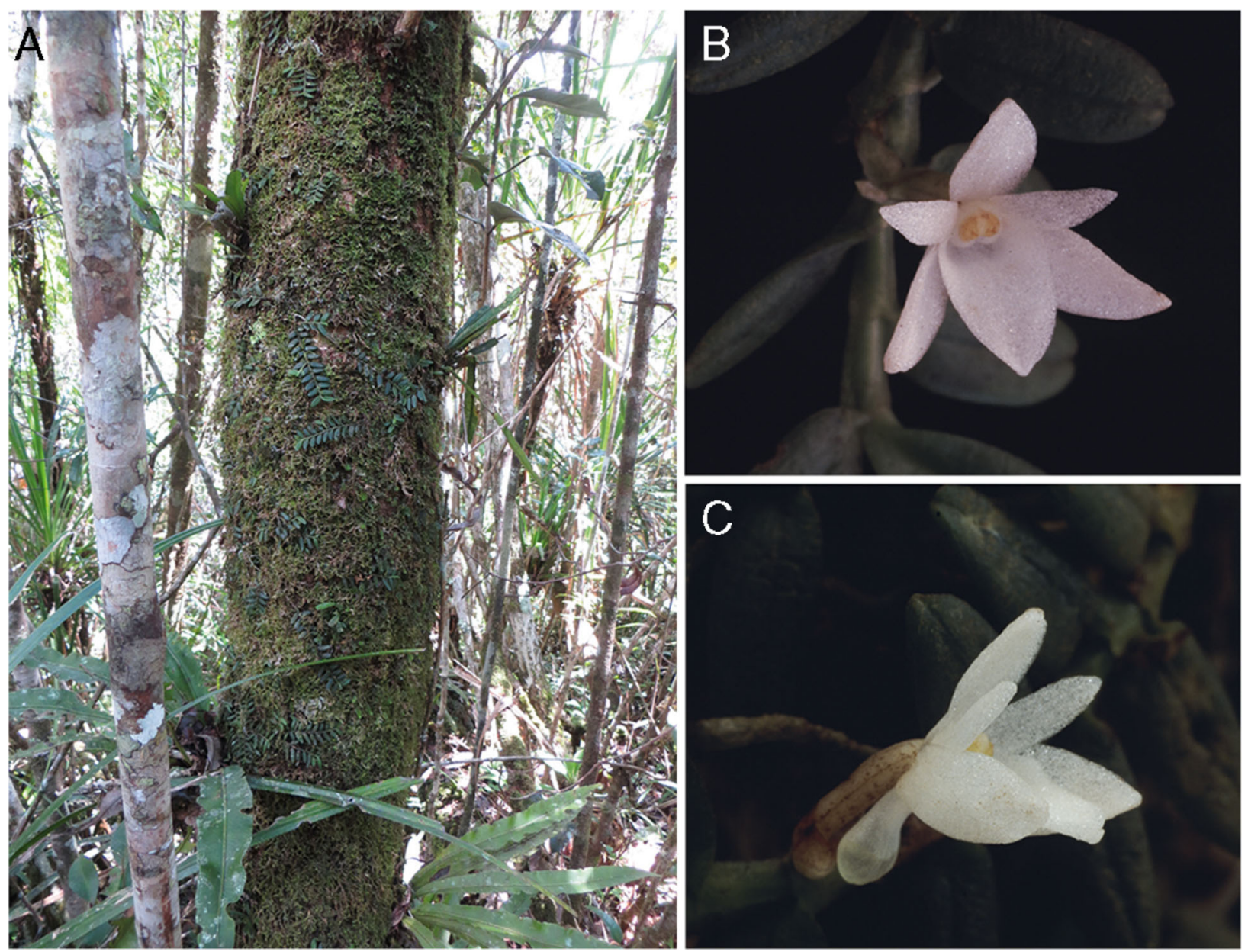

Fig. 6. Angraecum rotundifolium. A plant in habitat; B flower, face view; C flower, lateral view. PHOTOS: J. HERMANS.

less than $500 \mathrm{~km}^{2}$, the extent of occurrence EOO less than $5,000 \mathrm{~km}^{2}$ and three threat locations defined. The species is threatened by habitat destruction due to logging forest and shifting agriculture that cause the continuing decline in the EOO, AOO and the habitat quality. This species is therefore assessed as

Table 2. Comparison of Angraecum dasycarpum and A. rotundifolium.

\begin{tabular}{|c|c|c|}
\hline & Angraecum dasycarpum & Angraecum rotundifolium \\
\hline Plant & $10-15 \mathrm{~cm}$ long, branching & 7 - $10 \mathrm{~cm}$ long, branching \\
\hline Leaves & $\begin{array}{l}\text { horizontal or slightly divergent to the stem, ovate-lanceolate, } \\
\quad 7-1 \times 4.7-6 \mathrm{~mm}\end{array}$ & $\begin{array}{l}\text { flat against the substrate, elliptic to oblong, } \\
1.8-2.2 \times 1-1.3 \mathrm{~mm}\end{array}$ \\
\hline Ovary & $5-7 \times 1.1-1.9 \mathrm{~mm}$, with soft pubescent hairs & $3-5 \times 0.9-2 \mathrm{~mm}$, echinate to shortly hirsute \\
\hline Floral bracts & $5-7 \times 2-3 \mathrm{~mm}$ & $1.8-2.2 \times 1-1.3 \mathrm{~mm}$ \\
\hline Dorsal sepal & $7-8.3 \times 2-4.1 \mathrm{~mm}$ & $4-5 \times 1.8-2 \mathrm{~mm}$ \\
\hline Lateral sepals & $7-10 \times 2-4 \mathrm{~mm}$ & $4.2-6 \times 1.8-2 \mathrm{~mm}$ \\
\hline Petals & $6-8.5 \times 1.2-3 \mathrm{~mm}$ & $3.3-4.2 \times 0.8-1.2 \mathrm{~mm}$ \\
\hline Lip & $5.5-10 \times 2-3.6 \mathrm{~mm}$ & $4-5 \times 2.5-3.8 \mathrm{~mm}$ \\
\hline Spur & $\begin{array}{l}3-4 \times 0.8-1 \mathrm{~mm} \text {, cylindrical, slightly narrowing towards the } \\
\text { obtuse apex }\end{array}$ & $\begin{array}{l}1-1.2 \times 1-1.2 \mathrm{~mm} \text {, cylindrical towards the } \\
\text { base then flattened scrotiform at the apex }\end{array}$ \\
\hline Column & $\begin{array}{l}1-1.2 \times 1-1.2 \mathrm{~mm} \text { with distinct falciform lateral lobes of the } \\
\text { rostellum folded in front of the rostellum, small subulate central } \\
\text { lobe }\end{array}$ & $\begin{array}{l}1.1-2 \times 1.1-1.3 \mathrm{~mm} \text {, short rounded lateral } \\
\text { lobes of the rostellum, small obtuse central } \\
\text { lobe }\end{array}$ \\
\hline Distribution & N E Madagascar & E \& Central Madagascar \\
\hline Altitude (m) & $0-300$ & $600-1000$ \\
\hline Flowering time & August to November & February to May \\
\hline
\end{tabular}


Endangered (EN) under criterion Blab(i,ii,iii)+ 2ab(i,ii,iii).

FLOWERING TIME. February to May.

ETYMOLOGY. The epithet name refers to the typical rounded leaves.

\section{Evaluation of Pectinariella}

The genus Pectinariella was created by Szlachetko et al. (2013: 18) and is broadly based on Bentham's Mystacidium Lindl. (Lindley 1837: 205) section Pectinaria Benth. (Bentham 1883: 585) with Angraecum pectinatum Thouars (1822: t.51) as the type species. Cordemoy (1899: 412) considered it a genus in its own right, but Pectinaria cannot be used again at genus level because of its previous use in other plant families (Bernhardi 1800 in Apiaceae; Haworth 1819 in Apocynaceae and Hackel 1887 in Poaceae). Schumann (1901: 467) placed A. pectinatum in Ctenorchis and Kuntze (1903: 200) in Epidorchis sect. Pectinaria. Garay (1973: 499) in his review of the genus Angraecum defined section Pectinaria, based on Bentham's characteristics as follows: "stem elongate, loosely leafy, leaves alternate, fleshy, elongate, linear or with distinct blade, but never equitant, inflorescence one-flowered, peduncle very short or scarcely developed, sessile, flowers small". Micheneau et al. (2008) in their analysis of the angraecoid orchids, using a limited number of samples, concluded that the section does not appear to be natural and is represented in two clades. Cribb in Pridgeon et al. (2014: 362), based on Micheneau et al. (2008), also concluded that the section may be separated from Angraecum sensu stricto when further information became available. Szlachetko et al. (2013) in their re-classification of the Angraecum-alliance picked up on the comments by previous authors to describe four new genera and elevated the section Pectinaria to generic rank as the new genus Pectinariella (misspelled as 'Pectianriella' in the abstract), together with another ten sections of Angraecum. All the species placed in the section Pectinaria by Garay were transferred without substantiation to Pectinariella. Angraecum pterophyllum H.Perrier (1938: 106) was not considered by Szlachetko et al. (2013), probably because it was listed as a synonym of $A$. hermannii (Cordem.) Schltr. (Schlechter 1915: 424) by Garay. Accordingly the same authors did not acknowledge that A. hermannii was transferred to section Lemurangis Garay (1973: 501) by Micheneau et al. (2008: 915) and that A. pterophyllum was recognised as a valid species by them. Szlachetko et al. (2013: 18) stated that the new genus is "easily distinguishable from all other Angraecinae by its peculiar habit that is fleshy leaves, basally twisted with almost sessile flowers forming single-flowered inflorescence and ecallose lip". In the accompanying key the leaves are said to be conduplicate, the spur filiform and mostly longer than the ovary, whilst in the description the spur is said by the same authors to be predominantly subequal in length to the ovary and the leaves linear to linear-lanceolate. These characters do not apply to several species that were included in Pectinariella: the leaves of A. dasycarpum are flat, ovate-lanceolate and not conduplicate, linear to linear-lanceolate; the spur of $A$. gabonense Summerh. (Summerhayes 1954: 587) and A. dasycarpum are about equal to the length of the ovary; $A$. subulatum Lindl. (Lindley 1837: 206) and several other recently described 'Pectinariella' have two-flowered inflorescences (vs single-flowered) (Verlynde et al. 2016: 228). In addition, the definition could apply to a number of species traditionally assigned to other sections, including A. baromii (Finet) Schltr. (Schlechter 1915: 431). It is also puzzling that Szlachetko et al. (2013) included A. dasycarpum in their new genus despite the evidence presented in their cladogram (2013: 6) placing it amongst a group of morphologically very different species in section Perrierangraecum Schltr. (Schlechter 1925: 309). This could be due to an error in identification. No voucher information is provided for the specimens used in the research to account for possible misidentifications.

Simo-Droissart et al. (2013) confirmed the polyphyly of Angraecum section Pectinaria and found the continental African species to be closely related to section Dolabrifolia (Pfitzer) Garay (1973: 499). Verlynde et al. (2016) provided a detailed account of Pectinariella, recognising six species from Madagascar and the Mascarenes of which two were newly described and one was transferred from Angraecum as Pectinaria pterophylla (H.Perrier) Verlynde \& Ramand. Verlynde et al. (2016) did not include A. panicifolium H.Perrier (1938: 105) in their study even though Simo-Droissart et al. (2013: 303) found it to be close to Pectinariella pectinata (Thouars) Szlach., Mytnik \& Grochocka. More recently, Simo-Droissart (2018a) reconfirmed that Pectinariella is polyphyletic and advocated that the continental African species should be moved to a different genus. The newly established genus Afropectinariella M.Simo \& Stévart was later published to accommodate these finding (Simo-Droissart 2018b: 82).

The acceptance of Pectinariella is here brought into doubt by a number of factors: the flawed delimitation of Pectinariella; the lack of voucher specimens cited in some of the research outlined above; the doubt over some identifications; the limited number of species included in the analyses; the lack of consistency of the morphological features cited; and the distribution of the different species included in the genus. It is likely that some of the species of Pectinariella belong in different sections or genera. In combination with this lack of evidence, we consider that it is desirable to maintain the large genus Angraecum, instead of a number of small genera with overlapping morphologies, especially as the phylogenetic analysis of Angraecum s.l. is still incomplete. Several new species have been added recently to the section and the relationship between the continental African species and those from Madagascar and surrounding islands, and therefore with the type species, is still unclear. It is 
therefore prudent to maintain section Pectinaria of Angraecum, excluding the species recently transferred to Afropectinariella, for the time being. In agreement with this treatment the necessary new combinations are made below.

It is likely that further research will show that the species allied to Angraecum pterophyllum with an uppermost lip, an inflorescence with one or two flowers and an anther cap with a lobular extension, need to be separated from those allied to A. pectinatum with single flowers and a lip similar to the petals and sepals.

Angraecum sect. Pectinaria (Benth.) Schltr. (Schlechter 1918b: 157).

Mystacidium sect. Pectinaria Benth. in Benth. \& Hook.f.

(Bentham 1883: 585).

Pectinaria (Benth.) Cordem. (Cordemoy 1899: 412) nom. illeg.

Epidorchis sect. Pectinaria (Benth.) Kuntze (1903: 200). Pectinariella Szlachetko et al. (2013: 18) synon. nov.

Angraecum edmundi (Bosser ex Verlynde E Ramand.) Hermans $\mathcal{E}$ Verlynde comb. nov. Type: Madagascar, Antananarivo, Analamanga, Ankazobe, Tampoketsa d'Ankazobe, 1110 m, March 1962, Bosser Eं Peyrot 15441 (holotype P!).

http:/ /www.ipni.org/urn:lsid:ipni.org:names:77211714-1

Pectinariella edmundi Bosser ex Verlynde \& Ramand., Adansonia 38: 226 (in Verlynde et al. 2016) synon. nov.

Angraecum scroticalcar (Verlynde $\mathcal{E}$ Ramand.) Hermans $\mathcal{E}$ Verlynde comb. nov. Type: Madagascar, Toamasina, Aloatra-Mangoro, Moramanga, Ambatovy forest, 1057 - 1115 m, Aug. 2012, Ambatovy Spirit Collection 414A45/2 (holotype BRLU!; isotype TAN!).

http:/ /www.ipni.org/urn:lsid:ipni.org:names:77211715-1

Pectinariella scroticalcar Verlynde \& Ramand., Adansonia 38: 221 (in Verlynde et al. 2016) synon. nov.

\section{The identity of Angraecum dasycarpum}

Angraecum dasycarpum Schltr. (Schlechter 1918a: 337); Schlechter (1932: icon t. 88 nr 352; Fig. 7); Perrier (1941: 238); Hillerman \& Holst (1986: 246); Senghas (1986: 944); Bechtel et al. (1992: 59); Stewart et al. (2006: 127); Hermans et al. (2007: 39); Cribb \& Hermans (2009: 326); Bosser \& Lecoufle (2011: 127). Type: Madagascar, Laggiara s.n. (holo. $\mathrm{B} \dagger$ ). Neotype designated here: Madagascar, Forêt côtière $\mathrm{N}$ de Fénérive [Fenoarivo], Avril 1963, Bosser 17546 (P00098461) (neotype P!).

Pectinariella dasycarpa (Schltr.) Szlach., Mytnik \& Grochocka (Szlachetko et al. 2013: 18) synon. nov.

Erect, caespitose, epiphytic or lithophytic herb, up to $14 \mathrm{~cm}$ high, on a short branching stem; roots wiry, branching, greyish-white, puberulent, $0.5-1 \mathrm{~mm}$ in diam. Stem somewhat fleshy, branching, up to $12 \mathrm{~cm} \times$ 3-4 $\mathrm{mm}$, flattened, the margins winged, carrying up to 20 leaves, pale green. Leaves fleshy, alternate, distichous, horizontal or slightly divergent to the stem, ovate-lanceolate, $7-10 \times 2.3 \mathrm{~mm}$, flat with an indistinct mid-vein, with a central ridge underneath, almost sessile at the base, unequally bilobed at the tip, pale green, faveolate with dark pits on the upper and lower surface and a darker mid-vein. Inflorescence single-flowered, leaf-opposed, almost sessile with a 1.5 - $3 \mathrm{~mm}$ peduncle. Sheaths 1 to rarely 2, amplexicaul, lanceolate, $5-7 \times 2-3 \mathrm{~mm}$, compressed, brown. Flowers stellate, $16-21 \times 13-20 \mathrm{~mm}$, pure white with the column and anther yellowing with age. Pedicel and ovary fusiform, $5-7 \times 1.1-1.9 \mathrm{~mm}$, densely pubescent (appearing shortly hirsute in dried specimens). Dorsal sepal lanceolate, acute, $7-8.3 \times 2-4.1 \mathrm{~mm}$, recurved toward the tip. Lateral sepals oblong, acute, $7-10 \times 2-$ $4 \mathrm{~mm}$, divergent. Petals ligulate, $5-8.5 \times 1.2-3 \mathrm{~mm}$, recurved toward the tip, slightly concave. Lip narrowly elliptic, $5.5-10 \times 2-3.6 \mathrm{~mm}$, slightly narrowed in the middle, with long narrow wings towards the base, apex acute and a little recurved; spur parallel to the ovary, cylindrical, slightly narrowing towards the obtuse apex, $3.1-4 \times 0.8-1 \mathrm{~mm}$. Column very short, rounded, $1.1-$ $2 \times 1.1-1.3 \mathrm{~mm}$, with indistinct rounded lateral rostellum lobes, apex of rostellum deeply emarginate with a small subulate central lobe, stigma oval, c. $0.7 \mathrm{~mm}$ in diam. Anther cap semi-globose with a raised median ridge, $1-1.3 \times 0.8-1.2 \mathrm{~mm}$; pollinia 2 , ovoid, c. $0.3 \times 0.4 \mathrm{~mm}$, inserted directly on two contiguous strap-like stipes, distinct but partly fused by a small viscidium on each, c. $0.5 \mathrm{~mm}$ long. Seed capsule pubescent, oval, c. $3 \times 2 \mathrm{~mm}$. Figs 7,8 .

DISTRIBUTION. NE Madagascar, Toamasina province. SPECIMENS EXAMINED. MADAGASCAR. Without exact provenance, Laggiara s.n. (holotype $\mathrm{B} \dagger$ ); Île Sainte Marie, 1847 - 1852, Boivin 1693 (P!); Toamasina prov., Soanierana-Ivongo, Manompana, 9 Sept. 1959, Rauh M211 (HEID250201!) \& Rauh M210a (HEID250201!) (HEID 250167!); Toamasina prov., Maroantsetra, 12 Sept. 1959, Rauh M254 (HEID250201!) (HEID250202!); Toamasina prov., towards Fenoarivo, 19 Sept. 1959, Rauh M417 (HEID250201!) (HEID250203!); N of Fenoarivo, 1963, Bosser 17546 (neotype P!); Maroantsetra, Bosser 14653 (TAN!); Maroantsetra, Herb. Jard. Bot. Tana, Lambert 451 (P!). 


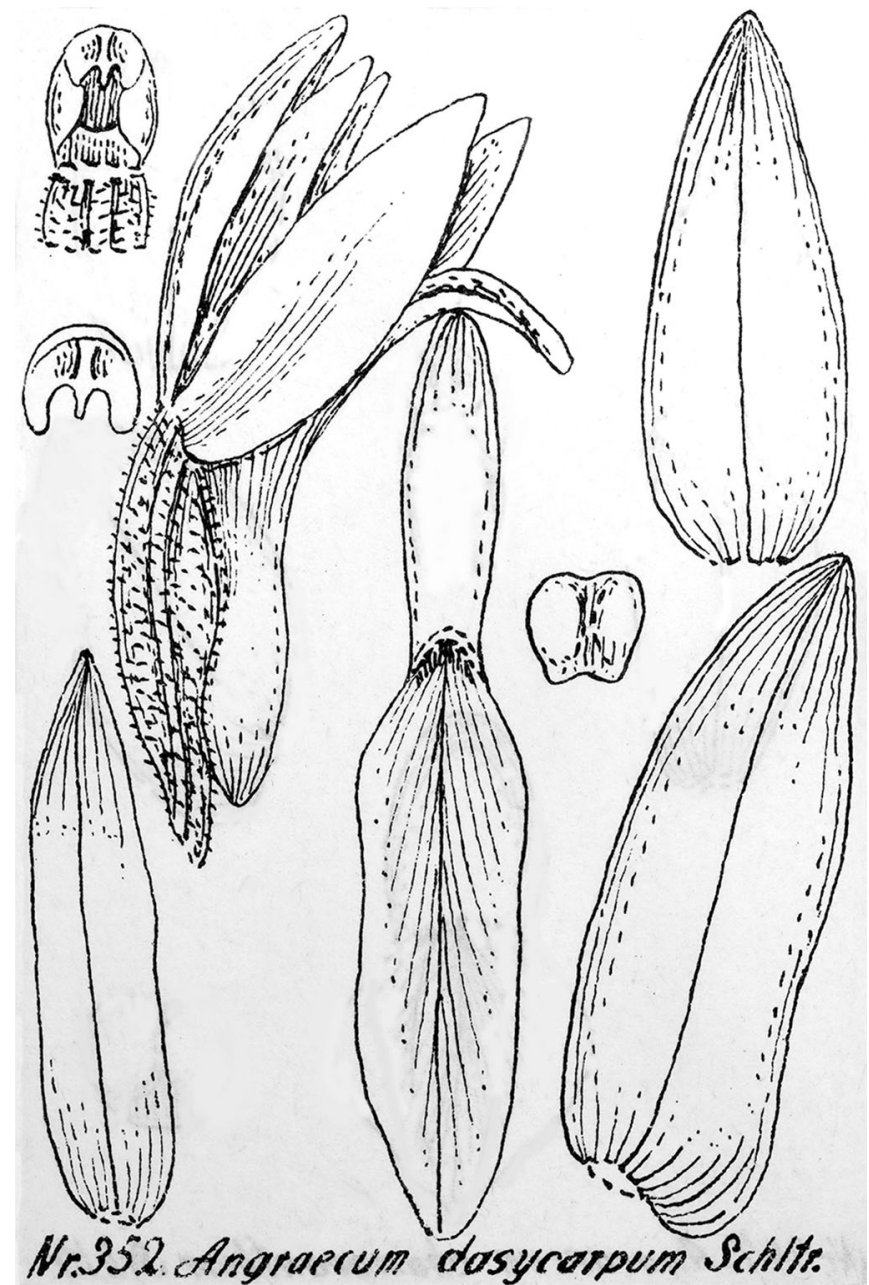

Fig. 7. Angraecum dasycarpum in Schlechter (1932).

HABITAT. Lowland evergreen coastal forest, on rocks covered in moss, on Philippia, in shade. Altitude 0 $300 \mathrm{~m}$.

CONSERVATION STATUS. Angraecum dasycarpum is endemic to Madagascar, distributed in Analanjirofo region, Toamasina province. It does not occur in any Protected Area. The area of occupancy AOO is estimated to be less than $500 \mathrm{~km}^{2}$, the extent of occurrence EOO less than $5,000 \mathrm{~km}^{2}$ and three threat locations defined. The species is threatened by habitat destruction due to logging forest and shifting agriculture that cause the continuing decline in the EOO, AOO and the habitat quality. This species is therefore assessed as Endangered (EN) under criterion Blab(i,ii,iii)+ 2ab(i,ii,iii).

FLOWERING TIME. August to November.

ETYMOLOGY. Referring to the rough-pubescent seed capsule/ovary.

NOTES. Angraecum dasycarpum, in section Pectinaria, is characterised by its caespitose branching plant with fleshy ovate-lanceolate distichous leaves, its stellate flowers that are relatively large for the section, with a pubescent ovary covered with soft hairs, an elliptic lip, a cylindrical spur narrowed towards the apex and a short column with an obtuse central lobe. It is a low-elevation species from the more tropical north-east of Madagascar. The flowers are similar to those of $A$. pectinatum and $A$. humblotianum but it has a different habit with broader and rounder leaves, and a distinct lip and spur shape. Other differences are discussed above under A. rotundifolium and shown in Table 2.

Angraecum dasycarpum was described by Schlechter (1918a) together with a group of other orchids from Madagascar collected by Laggiara. Although he was involved in describing almost half of the orchid flora of Madagascar, Schlechter never visited the island. He relied on other explorers for his material; mostly from the Frenchman Henri Perrier de la Bâthie but also from a few others. One of these was Dr Paolo Ferko, an Italian orchid grower and occasional importer who in turn received orchids collected in Madagascar by a Mr Laggiara. Not much is known about the collector apart from the fact that he collected in north-eastern Madagascar at the beginning of the $20^{\text {th }}$ century (Dorr 1997: 251). Very little of the Schlechter herbarium has survived in Berlin (B) and the holotype specimen of 


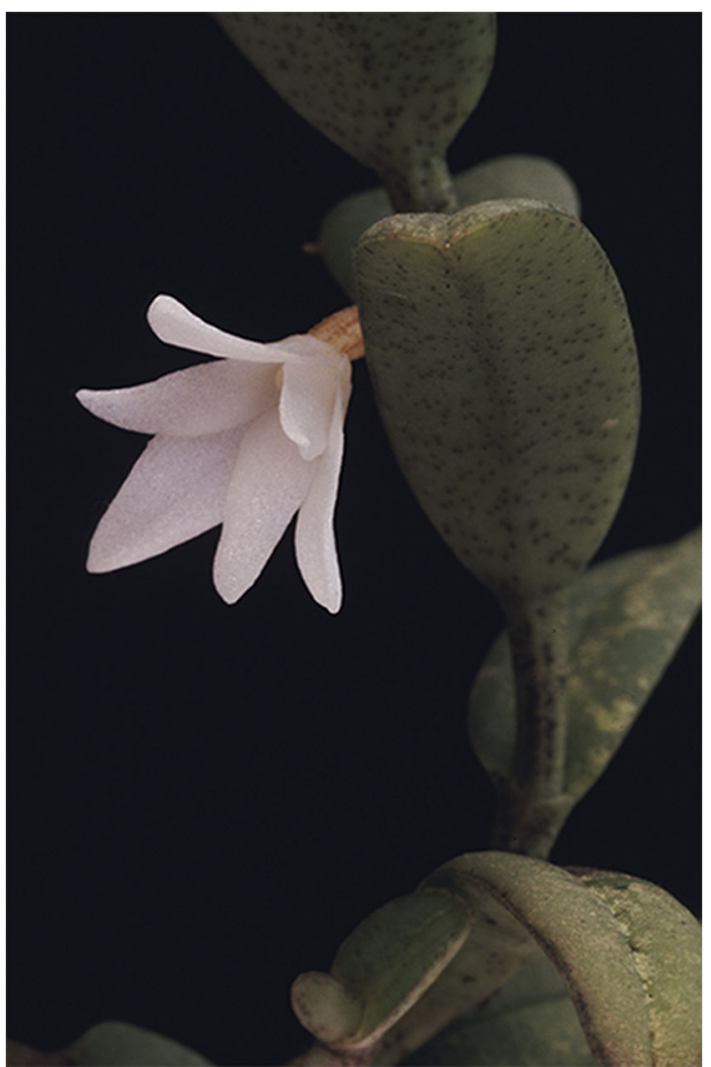

Fig. 8. Angraecum dasycarpum, flower. PHOTO J. HERMANS.

A. dasycarpum must therefore be considered destroyed in the 1943 fire (Butzin 1978, 1981); no Laggiara specimens have been found in other herbaria. The only surviving material associated with the type is the small illustration by Schlechter (1932: t. 88 no 352): the drawing is not detailed but it does show the main characteristics of the flower. It is possible that the illustration was based on material associated with the type but there is no direct evidence of this, furthermore, it was published well after the protologue and for these reasons cannot be considered as a lectotype. Schlechter's 1918a description is also limited in detail but, combined with the illustration, does provide sufficient information to identify the species with some certainty. A specimen collected by Bosser in 1963 (Bosser 17546 in P!) is designated here as the neotype of $A$. dasycarpum because it is well-documented, consists of several complete plants and flowers showing all the typical characteristics of the species. Other complete specimens were collected by Walter Rauh in northern Madagascar (Rauh M211 (HEID-spirit)) and illustrated in Senghas (1997: 103).

Szlachetko et al. (2013) transferred the species to their new genus Pectinariella, which is here placed back in Angraecum; the reasons for this are discussed above under the evaluation of the status of Pectinariella.

\section{The identity of Angraecum ochraceum}

Angraecum ochraceum (Ridl.) Schltr. (Schlechter 1915: 436; 1918b: 163); Perrier (1941: 221); Hillerman \&
Holst (1986: 259); Bechtel et al. (1992: 61); Stewart et al. (2006: 107); Hermans et al. (2007: 53); Cribb \& Hermans (2009: 372); Bosser \& Lecoufle (2011: 150); Hervouet (2018: 128). Type: Madagascar, Ankafina (S. Betsileo), Deans Cowan s.n. BM000539207! (holotype $\mathrm{BM}$ ); epitype designated here: illustration by Cowan (1880: 4) watercolour number 7; Fig. 9.

Mystacidium ochraceum Ridl. (Ridley 1885: 488).

Epidorchis ochracea (Ridl.) Kuntze (1891: 660).

Macroplectrum ochraceum (Ridl.) Finet (1907: 26).

Boryangraecum ochraceum (Schltr.) Szlach., Mytnik \& Grochocka (Szlachetko et al. 2013: 12).

Angraecum setipes Schltr. (Schlechter 1925: 340); Perrier (1941: 223); Hillerman \& Holst (1986: 246): Stewart et al. (2006: 107); Hermans et al. (2007: 63); Cribb \& Hermans (2009: 326); Bosser \& Lecoufle (2011: 164); Hervouet (2018: 144). Type: Madagascar, Mt Tsiafajavona (Ankaratra), H. Perrier 13988 P00541580! (holotype P), synon. nov.

Hermansia setipes (Schltr.) Szlach., Mytnik \& Grochocka (Szlachetko et al. 2013: 15), synon. nov.

Slender epiphytic herb up to $14 \mathrm{~cm}$ high, roots glabrous to slightly verrucose, silvery white $2-3 \mathrm{~mm}$ in diam.; stem short, $1-3 \mathrm{~cm}$ long, c. $1 \mathrm{~cm}$ in diam., completely covered by the greenish brown corrugate leaf sheaths, with $3-7$ leaves forming a broad fan. Leaves ligulate, $4-11 \times 0.5-1$ $\mathrm{cm}$, narrowed and conduplicate at the base, with a central groove a little revolute at the margins, unequally roundly bilobed at the apex, pale to dark green. Inflorescence erect to erectly spreading, filiform, up to $11 \mathrm{~cm}$, with $1-2$ short tubular sheaths, with 1 or rarely 2 flowers. Floral bract thintextured, ovate, acuminate, $2-2.5 \times 1-1.5 \mathrm{~mm}$, brown. Flowers with the lip uppermost, $22-32 \times 10-14 \mathrm{~mm}$, yellowish green to ochre yellow, somewhat lustrous. Pedicel and ovary subcylindrical, $4-9 \times 0.5-1 \mathrm{~mm}$, yellowish, strongly twisted, grooved, often with a some black scales within the grooves. Dorsal sepal broadly lanceolate, acute, $4.5-7 \times 1.8-3.1 \mathrm{~mm}$. Lateral sepals ovate, $4.8-7 \times 1.9-3$ $\mathrm{mm}$, spreading, attenuate. Petals lanceolate, $3.1-6.5 \times 1.2-$ $2 \mathrm{~mm}$, spreading, attenuate. Lip ovate to rhombic, obtuse to shortly acuminate at the tip, $5.2-6.8 \times 2.5-3.5 \mathrm{~mm}$, strongly concave to navicular, rarely with a few thin hairs towards the base; spur generally pendent but sometimes horizontal, $14-22 \times 0.6-2 \mathrm{~mm}$, subfiliform-cylindrical apex more or less thickened, sometimes with 3 elongate lobules. Column short, rounded, 1.5-2×1.3-1.8 mm, with short angular lateral rostellum wings, stigma oval, c. $1 \mathrm{~mm}$ in diam. Anther cap oblate, $1-1.5 \times 1-1.2 \mathrm{~mm}$; pollinia 2, subglobose, c. $0.5 \mathrm{~mm}$ in diam., distinct, with a small viscidium on each, c. $0.5 \mathrm{~mm}$ long. Figs $9-11$.

DISTRIBUTION. MADAGASCAR. Widespread, in Antananarivo, Antsiranana Fianarantsoa, Toamasina and Toliara provinces.

SPECIMENS EXAMINED. MADAGASCAR. Ankafina (S. Betsileo), Deans Cowan s.n. BM000539207! (holotype 


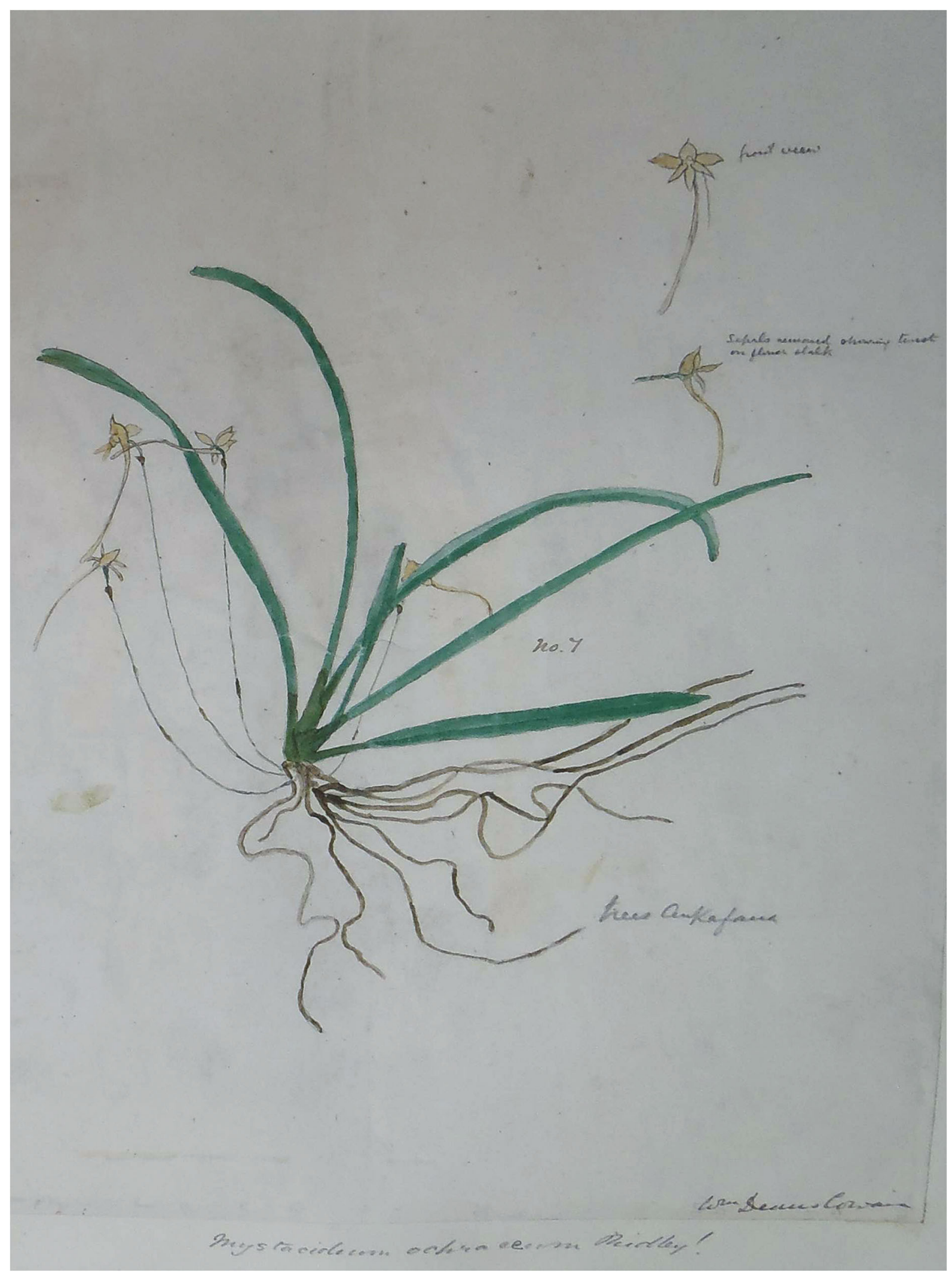

Fig. 9. Angraecum ochraceum, epitype. Watercolour 7 by Deans Cowan (1880). ๑ The Trustees of the Natural History Museum, London. 


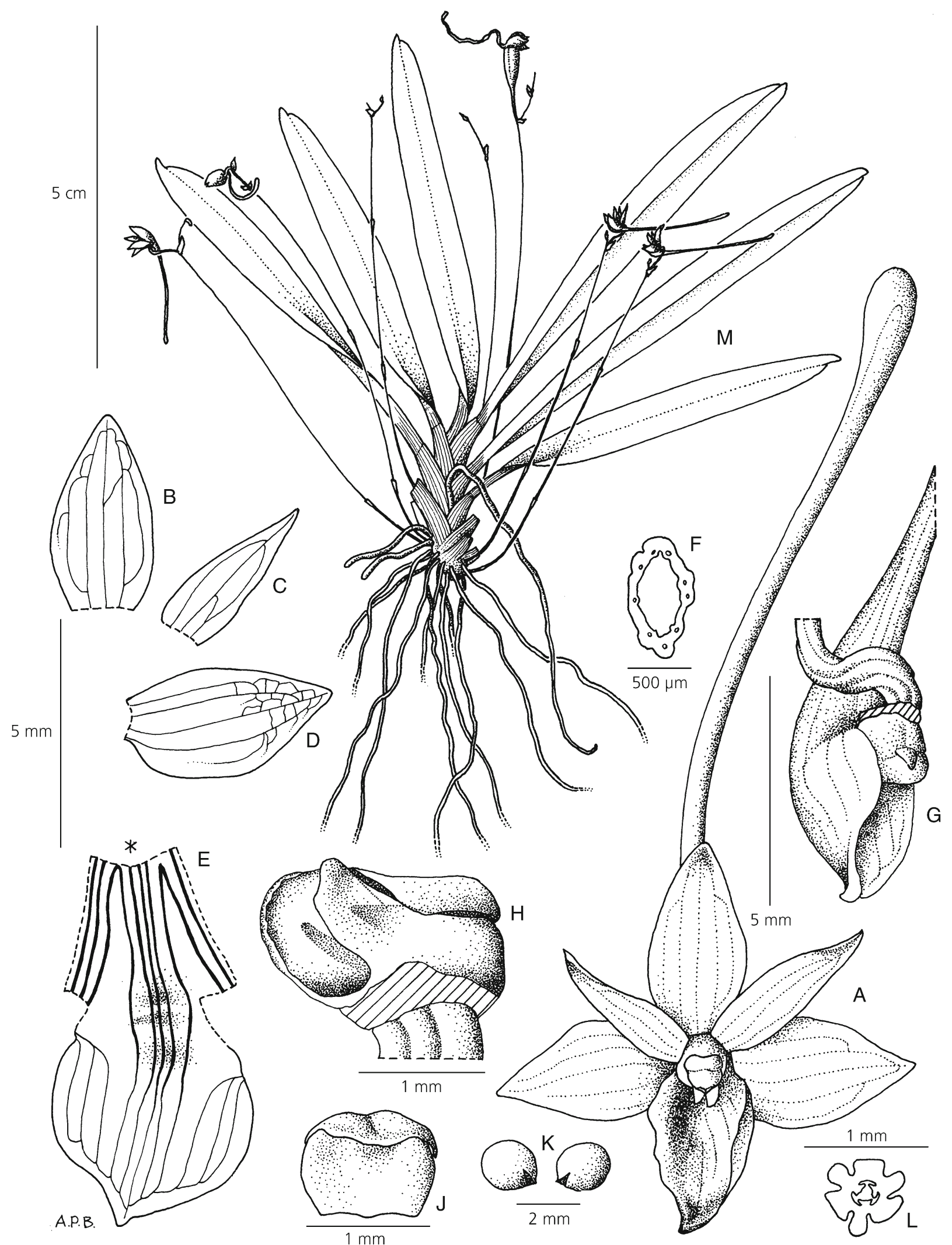

Fig. 10. Angraecum ochraceum. A flower, face view; B dorsal sepal; C petal; D lateral sepal; E lip \& proximal region of spur, flattened spur cut along dorsal mid-line; F T.S. spur at *; G column and lip, lateral view; H view of column, showing wings; J anther cap, dorsal view; K pollinia; L T.S. ovary; M habit. From DuPuy et al. M867. DRAWN BY ANDREW BROWN. 


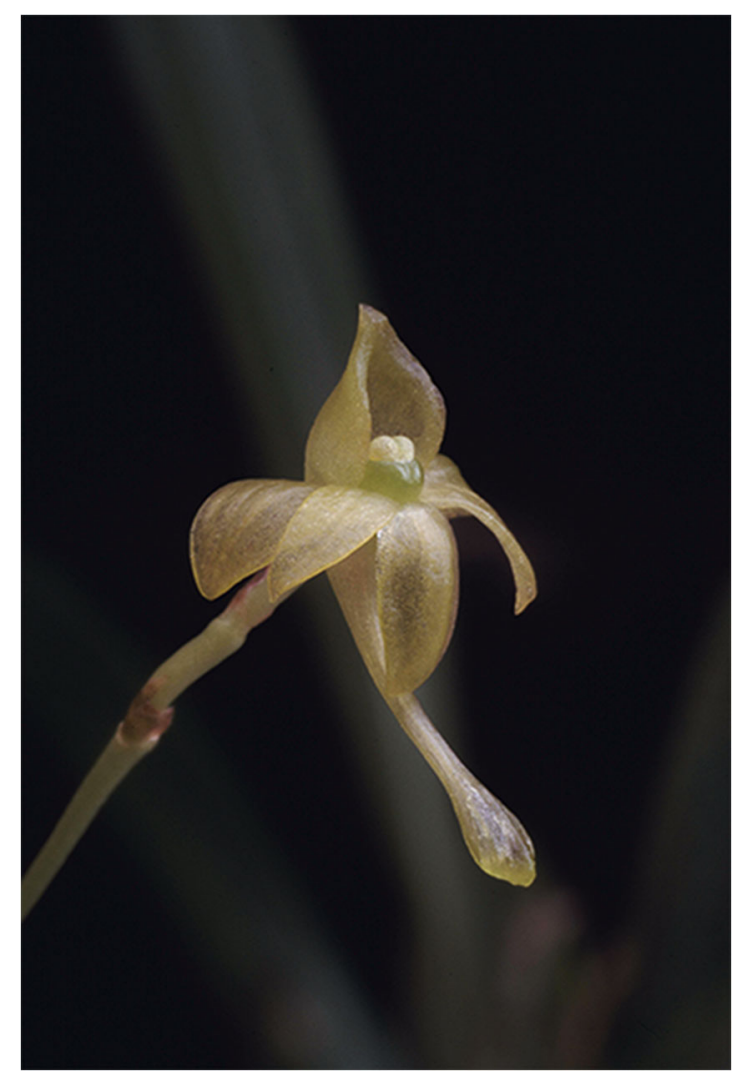

Fig. 11. Angraecum ochraceum flower. PHOTO: J. HeRMANS.

BM); Deans Cowan (1880: 4) watercolour number 7 (epitype BM!); Mt Tsiafajavona (Ankaratra), H. Perrier 13988, P00541580! (holotype P!); Scott-Elliot April 1890 (K!); Toamasina, Akanin'ny Nofy, 80 m, Nov. 1997, Hermans 4257 (K!); Andasibe forest, Onive basin, Feb. 1925, c. 1000 m, Perrier 17225, P1841419! (P); Andranomiadiloha, Vohiary, $20 \mathrm{~m}$, Nov. 1954, Rakotovae 637, P06168497! (P); Tampoketsa d'Ankazobe, Bosser 1078, P06168502! (P); Antsiranana, Montagne d'Ambre, Bosser 1261, (P!); Tampoketsa d'Ankazobe, Bosser 13276, P06168456! (P); Antananarivo, Angavokely Forest Reserve, 1700 m, March 1992, Petterson Eं Nilsson 583 (UPS!); Toamasina, Lake Aloatra, Manohilahy forest, $1300 \mathrm{~m}$, Jan. 1995, D. DuPuy et al. M821 (K!, TAN!); NW of Taolanaro, edge of Andohahela reserve, 610 m, Feb. 1995, D. DuPuy et al. M867 (K!); Antsiranana prov., Montagne d'Ambre, 1997, Hermans 8126 (K!); Antananarivo prov., road to Anjozorobe, 1550 - $1600 \mathrm{~m}$, Jan. 2000, Hermans 5201 K!); Fianarantsoa prov., near Ambatolahy, 1046 m, May 2001, Hermans 5567 (K!); Ranomafana NP, 1100 - 1250 m, Turk et al. 337 (MO!); Antananarivo, Analamanga Ambohitantely, $1570 \mathrm{~m}$, Nov. 2003, Lowry et al. 6266 (MO!); Toamasina, Aloatra-Mangoro, Menalamba, Ambatovy forest, 1180 m, March 2005, Antilahimena et al. 3704 (G!, MO!, P!, TAN!); Fianarantsoa Vatovavy-Fitovinany, Mananjary, Jan. 2007, 15 m, Sieder et al. 4060 (WU!); Ambatovy:
Région Alaotra-Mangoro, 1130 - 1133 m, Feb. 2012, Ambatovy spirit collection 230A563/3 (TAN); Analamanga, Anjozorobe, Ambohitsaratany, $1644 \mathrm{~m}$, March 2013, Ravololomanana et al. 279 (MO, P!, TAN!); Toamasina, Alaotra-Mangoro, Ambatovy: Région Alaotra-Mangoro, Jan. 2013, Ambatovy Spirit Collection 687A563/3 (BRLU, K!); Alaotra-Mangoro, Ambatovy, 1130 m, Jan. 2014, Ambatovy Spirit Collection 1312A563/ 3 (BRLU); Toamasina, Alaotra-Mangoro, Ambatovy: Région Alaotra-Mangoro, 1134 - 1151 m, Feb. 2015, Ambatovy Spirit Collection 2339A1277 (MO); Toamasina, Atsinanana, Vatomandry, 538 - 584 m, March 2016, Ambalabe Spirit Collection 102L92/7 (TAN!); Toamasina, Atsinanana, Ambalabe, piste vers Tsitondroina Antenanala, 603 - 677 m, Feb. 2016, Ambalabe Spirit Collection, 82L54/4 (MO); Toamasina, Atsinanana, Ambalabe, piste vers Tsitondroina - Antenanala, June 2017, 603 - 677 m, Ambalabe Spirit Collection, 191L54/4 (TAN!).

HABITAT. In humid evergreen forest, montane forest, on trees in moss. Altitude $538-2010 \mathrm{~m}$.

CONSERVATION STATUS. Angraecum ochraceum is endemic to Madagascar, has a large distribution range and is widespread in Antananarivo, Antsiranana, Fianarantsoa, Toamasina and Toliara provinces. It occurs in some Protected Areas such as Ambatovy, Ambohitantely, Andasibe-Mantadia, Andohahela, Montagne d'Ambre and Ranomafana. This species is therefore assessed as Least Concern (LC).

FLOWERING TIME. September to March but mainly in February.

ETYMOLOGY. The epithet ochraceum refers to the ochre colour of the flowers; setipes presumably refers to the thin bristle-like inflorescence.

NOTES. The species is recognised by the almost stemless medium-sized plant with thin ligulate leaves arranged into a fan, long filiform inflorescence with 1 (rarely 2) flowers, the strongly concave lip and long spur thickened towards the apex.

Angraecum ochraceum (as Mystacidium ochraceum) was placed by Ridley (1885: 488) in Mystacidium sect. Gomphocentrum Benth. (Bentham 1881: 337), whereas Schlechter (1918b: 163) transferred it into Angraecum section Lepervenchea Cordem. (Cordemoy 1899: 415). When describing A. setipes, Schlechter (1925: 341) placed it in his new section Boryangraecum Schltr. (Schlechter 1925: 308). Perrier (1941: 221, 223) put both $A$. ochraceum and $A$. setipes in the same group of section Boryangraecum. Garay created a new section Acaulia Garay (1973: 498) for acaulous species with a single flower, including $A$. setipes in it, while keeping A. ochraceum in section Boryangraecum. Szlachetko et al. (2013: 12, 15), when they split up the genus Angraecum, placed A. ochraceum in their new genus Boryangraecum (Schltr.) Szlach., Mytnik \& Grochocka and A. setipes in their new genus Hermansia Szlach., Mytnik \& Grochocka. Until a more comprehensive 
assessment of Angraecum s.l. is published it is perhaps best to leave the species unplaced at sub-generic level.

The thin single flowered-inflorescence and flower shape are similar to that of Angraecum rhynchoglossum Schltr. (Schlechter 1925: 339) but in that species the leaves are consistently shorter, smaller and oblong (vs ligulate), and the flowers are about a third larger. Other stemless species with long narrow leaves, a long thin peduncle and a single (rarely two) flower include: A. andasibeense H.Perrier (1938: 124), which has thinner and shorter, linear leaves (vs ligulate), flowers that are a third smaller with an ovate, acuminate lip (vs ovaterhombic) and an anther cap with a well-developed lobe at the front (vs entire); A. brachyrhopalon Schltr. (Schlechter 1925: 336) which is a slightly shorter plant, with narrowly linear leaves (vs ligulate), flowers that are a third smaller and have an incurved clavate spur (vs straight and slightly thickened at the end); and A. pumilio Schltr. (Schlechter 1916: 33) which is smaller by a third in all aspects and the $7 \mathrm{~mm}$ long spur is around half the size (vs at least $14 \mathrm{~mm}$ long).

Mystacidium ochraceum was described by Henry Ridley in 1885 , based on a collection by the Rev. William Deans Cowan from 'Ankafana' in Madagascar. Ankafana is a general name for the missionary post in the Fianarantsoa area of Madagascar (Christenson 1932: 9). The type specimen at BM is sterile with an indication of a flower in spirit but this has not been located and presumed lost. However, a watercolour ('no 7') can be found in Deans Cowan's sketchbook at the London Natural History Museum, London (Cowan 1880: 7) (Fig. 9), showing a flowering plant of the species which corresponds well with one of the plants on the herbarium sheet, it is annotated 'Mystacidium ochraceum Ridley' in Ridley's hand. On the type specimen Ridley also indicated the number '7', referring to Deans Cowan's watercolour, it can therefore be considered part of the type material used by Ridley especially as it complements the limited herbarium material and description; the illustration is therefore designated here as an epitype. In 1907 Finet placed the species in the genus Macroplectrum but based it on a Baron specimen donated by K to P. Schlechter (1918b) transferred the species to Angraecum. It is unlikely that Schlechter (1925) was familiar with the Deans Cowan specimen, let alone the watercolour, when he described Angraecum setipes, based on a Perrier specimen from the Ankaratra mountains in central Madagascar. When comparing the two taxa there is no doubt that they are conspecific, with the name A. ochraceum having precedence. In the broad range of specimens examined, it was found that the lip shape is a little variable with some flowers having a more deeply concave lip with a more pronounced acuminate apex but this variation occurred in different flowers on the same plant and may be dependent on the maturity of the flowers. The length of the spur too was found to be variable ranging from $14-22 \mathrm{~mm}$ : this was dependent on the stage of development of the flowers and also some variants consistently had a shorter spur but also smaller flowers. This variation is not unusual in other Angraecum species: on examination of over 25 specimens of the similar A. rhynchoglossum it was found that spur length ranged from $15-28 \mathrm{~mm}$ while in A. calceolus Thouars (1822: t. 78 ) the range was $10-18 \mathrm{~mm}$. The thickening towards the end of the spur was also found to be variable but it was consistently present. Considering this variability it seems reasonable to treat $A$. setipes as a synonym of a widespread and variable $A$. ochraceum.

\section{Acknowledgements}

We are most grateful to the directors and staff at BM, BR, BRLU, DUB, G, HEID, K, M, MO, P, SZU, TAN, TEF, W, WU, M, SZL and ZSS and their relevant libraries. We would like to sincerely thank the anonymous reviewers for their constructive suggestions and corrections, and Judi Stone and Andrew Brown for the detailed drawings. We are grateful to Anton Sieder and his colleagues of the Botanical Garden, University of Vienna, Austria for providing some of the herbarium material.

Open Access This article is licensed under a Creative Commons Attribution 4.0 International License, which permits use, sharing, adaptation, distribution and reproduction in any medium or format, as long as you give appropriate credit to the original author(s) and the source, provide a link to the Creative Commons licence, and indicate if changes were made. The images or other third party material in this article are included in the article's Creative Commons licence, unless indicated otherwise in a credit line to the material. If material is not included in the article's Creative Commons licence and your intended use is not permitted by statutory regulation or exceeds the permitted use, you will need to obtain permission directly from the copyright holder. To view a copy of this licence, visit http://creativecommons.org/ licenses/by/4.0/.

\section{References}

Andriananjamanantsoa, H., Engberg, S., Louis, E. \& Brouillet, L. (2016). Diversification of Angraecum (Orchidaceae, Vandeae) in Madagascar: Revised Phylogeny Reveals Species Accumulation through Time Rather than Rapid Radiation. PLoS ONE 11: e0163194.10.1371/journal.pone.0163194.

Bechtel, H., Cribb, P. \& Launert, E. (1992). The Manual of Cultivated Orchid Species. 3rd Edition. Blandford, London.

Bentham, G. (1881). Notes on Orchideae, J. Linn. Soc., Bot. 18: 281 - 358. 
(1883). In: G. Bentham \& J. D. Hooker, Genera Plantarum 3. A. Black, London.

Bory de St-Vincent, J. B. (1804). Voyage dans les quatre principales îles des mers d'Afrique: fait par ordre $d u$ gouvernement, pendant les années neuf et dix de la République (1801 et l802), avec l'histoire de la traversée du capitaine Baudin jusqu'au Port-Louis de l'île Maurice. F. Buisson Paris.

Bosser, J. (1970). Contribution à l'étude des Orchidaceae de Madagascar XII. Jumellea et Angraecum nouveaux. Adansonia 10: 95 - 110.

(1988). Contribution à l'étude des Orchidaceae de Madagascar XXIII. Adansonia 10: 19 - 24. (1989a). Contribution à l'étude des Orchidaceae de Madagascar XVIV. Adansonia 11: 29 - 38.

(1989b). Contribution à l'étude des Orchidaceae de Madagascar XXVI. Adansonia 11: 369 - 382.

(2007). Contribution à l'étude des Orchidaceae de Madagascar, des Comores et des Mascareignes. XXXVI. Description d'un Cynorkis nouveau de la Réunion et d'un Angraecum nouveau de Madagascar. Adansonia 14: 13 - 17.

\& Lecoufle, M. (2011). Les Orchidées de Madagascar. Biotope, Mèze.

Butzin, F. (1978). In Berlin vorhandene Typen von Schlechters Orchideenarten. Willdenowia 8: 401 - 407. (1981). Typenstudien im Berliner OrchideenHerbar: Diverse markierte Typen. Willdenowia 11: 119 - 121 .

Christenson, C. (1932). The Pteridophyta of Madagascar. Dansk. Bot. Ark. 7: 5 - 15.

Cordemoy, J. E. (1899). Orchidées de la Réunion. Rev. Gén. Bot. 11: 409 - 429.

Cowan, W. Deans (1880). Drawings of Madagascar Orchids, Natural History Museum. 581.9 (691), London.

Cribb, P. J. \& Hermans, J. (2009). Field Guide to the Orchids of Madagascar. Kew Publishing, Royal Botanic Gardens, Kew.

, Nusbaumer, L. \& Gautier, L. (2012). Angraecum darainense P.J.Cribb \& Nusb. and Aeranthes unciformis P.J.Cribb \& Nusb. (Orchidaceae), two new species from northern Madagascar. Candollea 67: $269-275$.

in Pridgeon, A. M., Cribb, P. J., Chase, M. W. \& Rasmussen F. N. (2014). Genera Orchidacearum, Epidendroideae (Part one) 4. Oxford University Press, Oxford.

Dorr, L. J. (1997). Plant Collectors in Madagascar and the Comoro Islands. Royal Botanic Gardens, Kew.

Finet, A. (1907). Classification et énumération des Orchidées africaines de la tribu des Sarcanthées, d'après les collections du Muséum de Paris. Bull. Soc. Bot. France 54: 1 - 65.

Garay, L. A. (1973). Systematics of the genus Angraecum (Orchidaceae). Kew Bull. 28: 495 - 516.
Govaerts, R., Bernet, P., Kratochvil, K., Gerlach, G., Carr, G., Alrich, P., Pridgeon, A. M., Pfahl, J., Campacci, M. A., Holland Baptista, D., Tigges, H., Shaw, J., Cribb, P., Kreuz, K. \& Wood, J. (2018). World Checklist of Selected Plant Families. Facilitated by the Royal Botanic Gardens, Kew. Published on the Internet: http://apps.kew.org/ wcsp/.

Guérin, J.-C. \& Hervouet, J.-M. (2011). Neuvième voyage à Madagascar: Ambondrombe, la montagne des morts, Orchidophile (Asnières) 42: 87 - 101.

Hermans, J. (2017). Some Angraecum Conundrums. Amer. Orchid Soc. Bull. 86: 448 - 457.

\& Cribb, P. J. (1997). A new species of Angraecum (Orchidaceae) from Madagascar. Orchid Rev. 105: $108-111$.

\& __ (2005). The Angraecum germinyanum complex. Orchid Rev. 113: 90 - 97. \& Bosser, J. (2002). A distinctive new species of Angraecum from Madagascar. Orchid Rev. 110: 22 - 23. Hermans, C., Du Puy, D., Cribb, P. J. \& Bosser, J. (2007). Orchids of Madagascar $2^{\text {nd }}$ edition. Kew Publishing. Royal Botanic Gardens, Kew.

\& La Croix, I. (2001). Angraecum clareae Hermans, la Croix \& P.J.Cribb sp.nov. Orchid Rev. 109: 43 - 46.

Hervouet, J-M. (2018). A la recherche des Orchidées de Madagascar. Biotope, Mèze.

Hillerman, F. E. \& Holst, A. W. (1986). An Introduction to the Cultivated Angraecoid Orchids of Madagascar. Timber Press, Oregon.

IUCN (2012). IUCN Red List Categories and Criteria: Version 3.1. 2nd edition. Gland and Cambridge. (2017). Guidelines for Using the IUCN Red List Categories and Criteria. Version 13. http:// w w w . i u c n r ed lis t . org / d o c u m en t s / redlist_guidelines_v1223290226.pdf.

Kuntze, O. (1891). Revisio Genera Plantarum 2. Arthur Felix, Leipzig.

(1903). In: T. E. von Post \& O. Kuntze, Lexicon Generum Phanerogamarum. Uppsala.

Lindley, J. (1837). In: W. J. Hooker (ed.), Notes upon some genera and species Orchidaceae. Compan. Bot. Mag. 2: $200-210$.

Micheneau, C., Carlsward, B. S., Fay, M. F., Bytebier, B., Pailler, T. \& Chase, M. (2008). Phylogenetics and biogeography of Mascarene angraecoid orchids (Vandeae, Orchidaceae). Molec. Phylogenet. Evol. 46: 908 - 922.

Perrier de la Bâthie, H. (1938). Sarcanthae nouvelles ou peu connues de Madagascar (fin). Notul. Syst. (Paris) 7: $105-139$.

(1941). In: H. Humbert, Flore de Madagascar. $49 e$. Famille. - Orchidées. Tananarive Imprimerie Officielle.

Ridley, H. N. (1885). The Orchids of Madagascar. J. Linn. Soc., Bot. 21: 456 - 523. 
Schlechter, R. (1915). Kritische Aufzählung der bisher von Madagaskar, den Maskarenen, Komoren und Seychellen bekantgewordenen Orchidaceen. Beih. Bot. Centralbl. 33: 390 - 440.

(1916). Orchidaceae Perrierianae (Collectio secunda). Beih. Bot. Centralbl. 34: 1 - 341.

(1918a). Additamenta ad Orchideologiam Madagascarensem. Repert. Spec. Nov. Regni Veg. Beih. 15: $324-340$.

(1918b). Versuch einer natürlichen Neuordnung der afrikanischen angraekoiden Orchidaceen. Beih. Bot. Centrabl. 36: 62 - 181.

(1924). Orchidaceae Perrieranae. Repert. Spec. Nov. Regni Veg. Beih. 33: 1 - 240.

(1925). Orchidaceae Perrieranae. Repert. Spec. Nov. Regni Veg. Beih. 33: 241 - 391.

(1932). In: R. Mansfeld (ed.), Blütenanalysen neuer Orchideen, Orchideen III. Afrikanische und Madagassische Orchideen, Repert. Spec. Nov. Regni Veg. Beih. 68: t. 1 - 68.

Schumann, K. M. (1901). Neue Arten der Siphonogamen 1899. Just's Bot. Jahresber. 27: 449 - 545.

Senghas, K. (1964). Sur Quelques Orchidées Nouvelles ou Critiques de Madagascar. Adansonia 4: 301 314.

(1986). Die Orchideen, Rudolf Schlechter. Blackwell, Berlin.

(1997). Vielfalt tropischer und suptropischer Orchideenstandorte und ihre Übertragung in die Kultur, dargestellt am Beispiel der Gattung Angraecum in Madagaskar mit einer neuen Art, Angraecum dollii. J. Orchideenfreund 4: 13 - 25.

Simo-Droissart, M., Micheneau, C., Sonké, B., Droissart, V., Plunkett, G. M., Lowry, P. P. II, Hardy, O. J. \& Stévart, T. (2013). Morphometrics and molecular phylogenetics of the continental African species of Angraecum section Pectinaria (Orchidaceae). Pl. Ecol. Evol. 146: 295 - 309.
Plunkett, G. M, Droissart, V., Edwards, M. B., Farminhão, J. N. M., Ječmenica, V., D’Haijère, T., Lowry, P. P. II, Sonké, B., Micheneau, C., Carlsward, B. S., Azandi, L., Verlynde, S., Hardy, O. J., Martos, F., Bytebier, B., Fischer, E. \& Stévart, T. (2018a). New phylogenetic insights toward developing a natural generic classification of African angraecoid orchids (Vandeae, Orchidaceae). Molec. Phylogenet. Evol. 126: 241 - 249.

Sonké, B., Droissart, V. \& Stévart, T. (2018b). Afropectinariella (Vandeae, Orchidaceae), a new genus of the Angraecum alliance. PhytoKeys. 96: 79 -86 .

Stewart, J., Hermans, J. \& Campbell, B. (2006). Angraecoid Orchids. Timber Press. Portland.

Summerhayes, V. S. (1954). African Orchids XXII. Kew Bull. 8: 575 - 591.

Szlachetko, D. L., Tukallo, P., Mytnik-Ejsmont, J. \& Grochocka, E. (2013). Reclassification of the Angraecum-alliance (Orchidaceae, Vandoidae) based on molecular and morphological data. Biodivers. Res. Conserv. 29: 1 - 23.

Thouars, A. du Petit (1822). Histoire particulière des Plantes Orchidées recueillies sur les trois Îles Australes d'Afrique. Bertrand, Treuttel \& Wurtz, Paris.

Verlynde, S., Ramandimbisoa, B., Bosser, J. \& Stévart, T. (2016). Contribution à l'étude des Orchidaceae de Madagascar. XXXVIII. Deux nouvelles espèces et une nouvelle combinaison pour le genre Pectinariella Szlach., Mytnik \& Grochocka à Madagascar. Adansonia 38: 219 - 232.

\section{Publisher's Note}

Springer Nature remains neutral with regard to jurisdictional claims in published maps and institutional affiliations. 